Espacio, Tiempo y Forma, Serie II, Historia Antigua, t. 23, 2010, págs. 279-305

\title{
El ágape y los banquetes rituales en el cristianismo antiguo*
}

\author{
The Agape and the Ritual Banquets in the Ancient Christianity
}

\author{
Raúl GonzÁlez SALINERO**
}

\begin{abstract}
RESUMEN
Asumiendo como propia la extendida costumbre del symposium en las sociedades antiguas, las comunidades cristianas celebraron, desde sus mismos inicios, banquetes o comidas rituales que sirvieron para fortalecer los vínculos comunitarios y asentar la propia identidad religiosa. En el seno de este tipo de reuniones, conocido al principio genéricamente con el término de ágape, surgió la comida eucarística. Las fuentes

literarias cristianas, desde los propios escritos neotestamentarios, nos hablan con cierta profusión de estos banquetes de carácter religioso y, a partir del siglo III, aparecen representados en pinturas $y$ mosaicos, en la mayoría de los casos vinculados a los ritos funerarios cristianos.
\end{abstract}

\footnotetext{
PALABRAS CLAVE:

Ágape, banquetes rituales, cristianismo antiguo
}

\begin{abstract}
The First Christian Communities did assume the widespread symposium habit of the Ancient societies as theirs. From the beginning, they celebrated banquets or ritual meals that were used to strengthen the community ties and to consolidate their own religious identity. At the bosom of this kind of gathering, originally known as the Agape term, did emerge the Eucharistic meal. From the New Testament writings, the Christian literary sources speak us with some profusion about the religious banquets, and, from the third century, they appeared represented on Christian funerary fresco paintings and mosaics.
\end{abstract}

KEYWORDS:

Ágape, Ritual banquets, Ancient Christianity

El presente estudio constituye la versión ampliada y anotada de la conferencia que ofrecí en Mérida el 10 de julio de 2009 dentro del XX Curso Internacional de Verano: Symposia. El banquete en el mundo antiguo (Museo Nacional de Arte Romano-UNED, Mérida).

${ }_{* *}$ Departamento de Historia Antigua (UNED). Paseo Senda del Rey, 7; 28040 Madrid. E-mail: rgsalinero@geo.uned.es. 
Haciendo suya la costumbre del symposium propia de las sociedades antiguas, las primeras comunidades cristianas celebraron, casi desde sus mismos inicios y sin que importara de qué tradiciones paganas o judías procediera, una comida en común o ágape de carácter religioso ${ }^{1}$. Existen indicios de que en un principio estos ágapes o banquetes comunitarios cumplían la doble función de saciar el hambre, especialmente de los acólitos más pobres ${ }^{2}$, y de asentar litúrgicamente un sacramento de unión y confraternización (1 Cor 11, 21-22), si bien es cierto que, a mediados del siglo II, ambas funciones aparecen ya finalmente separadas en la mayor parte de las comunidades cristianas ${ }^{3}$.

Ahora bien, los textos antiguos reflejan una gran diversidad en la interpretación religiosa del banquete fraternal ${ }^{4}$. Así, por ejemplo, mientras que la Didaché (un ordenamiento eclesiástico redactado probablemente en Siria a caballo entre los siglos I y II) relaciona el ágape con la vida, el conocimiento, la unidad y la inmortalidad (Did., 9, 4 y 10,2), las palabras de Pablo ponen de manifiesto su estrecha vinculación con el «cuerpo» de Jesús y la «nueva alianza» (1 Cor 11, 24-25). De hecho, sólo en los relatos posteriores de la Iglesia, el ágape (del que después se desgajaría la eucaristía) fue considerado como una conmemoración de la última cena y muerte de Jesús, aspecto éste ausente en los Hechos de los Apóstoles, para los cuales se trataba, en cambio, de una celebración «jubilosa» del fin de los tiempos (Hch 2, 46). Así mismo, el perdón de los pecados podía ser un salvífico efecto del ágape $(M t 26,28)$, circunstancia que podía postularse como atractivo aliciente para suscitar la participación activa de los miembros de la comunidad en el banquete fraternal (Did., 14, 1) ${ }^{5}$.

Ciertamente, de algunos textos neotestamentarios puede deducirse que el ágape fue instituido por el mismo Jesús cuando ordenó en la última cena a sus discípulos que la repitieran en su memoria $(\operatorname{Lc} 22,19 ; 1 \text { Cor } 11,24-26)^{6}$. En otro pasaje de su

1 Los testimonios son muy numerosos: 1 Cor 11, 17-34; Hch 2, 42-46; 2 Pdr 2, 13; Plinio el Joven, Epist., 10, 97, 7; Ignacio de Antioquía, Epist. Smyrn., 8, 1-2; Judas, 12; Clemente de Alejandría, Paed., II, 1, 3-7; Minucio Félix, Oct., 31; Tertuliano, Apolog., 39; Martirio de Perpetua y Felicidad, 5; etc.

2 Vid. W. A. Meeks, Los orígenes de la moralidad cristiana. Los dos primeros siglos (trad. J. M. Álvarez Flórez), Ariel, Barcelona, 1994 (= Yale University Press, New Haven/London, 1994), p. 115.

${ }^{3}$ M. Simon, Los primeros cristianos (trad. M. Lamana), EudebA, Buenos Aires, $1963^{2}$ (= Presses Universitaires de France, Paris, 1952), p. 41. Cfr. M. Simon y A. Benoit, El judaísmo y el cristianismo antiguo. De Antíoco Epífanes a Constantino (trad. I. Castells), Labor, Barcelona, 1972 (= Presses Universitaires de France, Paris, 1968), p. 121; Chr. Markschies, Estructuras del cristianismo antiguo. Un viaje entre mundos (trad. J. A. Padilla Villete), Siglo XXI, Madrid, 2001 (= Frankfurt am Main, 1997), p. 170.

${ }^{4}$ P. F. Bradshaw, «Continuity and Change in Early Eucharistic Practice: Shifting Scholarly Perspectives», en R. N. Swanson (ed.), Continuity and Change in Christian Worship, Oxford University Press, Oxford, 1999, p. 17.

5 M. Klinghardt, “Tomad y comed; éste es mi cuerpo”. Ágape e interpretación del ágape en el cristianismo primitivo», en P. Schmidt-Leukel (ed.), Las religiones y la comida (trad. L. Miralles de Imperial Llobet), Ariel, Barcelona, 2002 (= Keuzligen/München, 2000), pp. 37-38. Cfr. W. A. Meeks, «Social and Ecclesiastical Life of the Earlist Christians», en M. M. Mitchell y F. M. Young (eds.), The Cambridge History of Christianity, 1. Origins to Constantine, Cambridge University Press, Cambridge, 2006, pp. 165-167.

6 Vid. A. Destro y M. Pesce, L'uomo Gesù. Giorni, luoghi, incontri di una vita, Mondadori, Milano, 2008, pp. 105ss. y 121-122. Sin embargo, en opinión de D. E. Smith, la imagen de Jesús en las comidas en común respondía a una caracterización ideal desarrollada muy pronto en las primeras comunidades cristianas: vid. D. E. Smith, Del simposio a la eucaristía. El banquete en el mundo cristiano antiguo (trad. A. Moliner Fernández), Verbo Divino, Estella, 2009 (= Minneapolis, 2003), pp. 343ss. y 359ss. 
carta a los corintios Pablo afirma expresamente que el ágape se celebraba en recuerdo de la «muerte del Señor» ${ }^{7}$. No obstante, tales testimonios no dejan de ser minoritarios, mientras que en otros pasajes en los que se menciona la comida comunitaria falta no sólo la orden explícita, sino también su supuesta relación con la muerte de Jesús ${ }^{8}$.

En realidad, las supuestas diferencias entre ágape y eucaristía sólo pueden ser percibidas con claridad a partir de la nomenclatura empleada con posterioridad, cuando la liturgia institucionalizada de la Iglesia asignó significados diferentes a un comportamiento comunitario en el que, en origen, resultaba imposible discernir entre la parte correspondiente al incipiente sacramento y la que constituía el ágape fraternal $^{9}$. A finales del siglo III o principios del siglo IV, la diversidad de formas y rituales que caracterizó a los banquetes cristianos a lo largo del tiempo y el espacio ${ }^{10}$, sufrió un acusado proceso de uniformidad y estandarización institucional que acabaría paulatinamente con las costumbres locales mantenidas por numerosas iglesias. Si bien es cierto que el ágape «secularizado» continuó existiendo dentro de la comunidad de fieles, manteniéndose especialmente vivo en determinados círculos cristianos, no menos cierto es que la celebración propiamente eucarística extendió su campo litúrgico no sólo a las reuniones dominicales, sino también a toda una variedad de rituales conectados con el consumo simbólico de alimentos sacramentales, tales como las comidas de carácter funerario o aquellas que tenían lugar en honor a los mártires y santos cristianos. En los estadios más tempranos, sin embargo, tanto la eucaristía como el ágape propiamente dicho, fueron términos que se entrelazaban en el seno de la mayoría de las comunidades cristianas para referirse a la tradición de los banquetes litúrgicos y fraternales ${ }^{11}$. Podría afirmarse que la eucaristía como tal sacramento surgió en el ámbito del ágape cristiano como una parte ritualizada de la reunión fraternal de la comunidad ${ }^{12}$. De hecho, estos banquetes en común ya existían en Corinto cuando Pablo de Tarso trató de explicar de forma simbólica el sentido que los cristianos de esta ciudad debían dar al servicio religioso celebrado en el ámbito propio del ágape ${ }^{13}$. En este caso, según sus palabras, la eu-

7 Vid. D. E. Smith, op. cit., pp. 301ss.

8 M. Klinghardt, loc. cit., p. 39; A. McGowan, Ascetic Eucharists. Food and Drink in Early Christian Ritual Meals, Clarendon Press, Oxford, 1999, p. 21.

9 A. McGowan, «Food, Ritual, and Power», en V. Burrus (ed.), A People's History of Christianity, 2. Late Ancient Christianity, Fortress Press, Minneapolis, 2005, p. 147. Cfr. J. F. Keating, The Agapé and the Eucharist in the Early Church. Studies in the History of Christian Love-Feasts, AMS Press, New York, 1969 (= Methuen \& Co., London, 1901).

10 D. E. Smith, op. cit., p. 25.

11 A. McGowan, «Food, Ritual...», p. 156. M. J. Townsend fue uno de los primeros estudiosos que reaccionaron contra la historiografía tradicional que defendía la distinción, desde los mismos inicios cristianos, entre ágape y eucaristía (uno de cuyos exponentes fue W. D. Maxwell, An Outline of Christian Worship: Its Development and Forms, Oxford, University Press, London, 1949), considerando que no era posible corroborar esa teoría en los escritos neotestamentarios y que ambas realidades se encontraban invariablemente unidas en los tiempos apostólicos. Vid. M. J. Townsend, «Exist the Agape?», Expository Times, 90 (12), 1979, p. 256.

12 Vid. en general, M. Symons, «From Agape to Eucharist: Jesus, Meals, and the Early Church», Food and Foodways, 8, 1999-2000, pp. 33-54.

131 Cor 11, 17-34. Respecto a este particular, W. A. Meeks afirma que para Pablo «la muerte de Cristo por todos, simbolizada en la Cena, entraña que los que participan en ésta deben poner las necesidades y sentimientos mutuos por delante de la honra privada. Es evidente que esa vinculación no había 
caristía, definida a veces también como fractio panis (Hch 2, 42; 20, 7), debía ser un acto litúrgico en recuerdo de la muerte de Jesús: el pan es «mi cuerpo para vosotros», y el cáliz es «la nueva alianza en mi sangre» (1 Cor 11, 23-26; cfr. 1 Cor $10,16)^{14}$. Ahora bien, no habría que olvidar que las comidas rituales de los primeros cristianos parecen compartir una fórmula similar de «acción de gracias» (eucharistía) o bendición (eulogia), razón por la que, para algunas comunidades, la eucaristía pudo considerarse posteriormente como aquella «comida común» en la que la acción de gracias ocupaba un lugar central ${ }^{15}$.

En la interpretación de G. Jossa, el desorden frecuente en este tipo de banquetes, tan vigorosamente denunciado por Pablo en su primera carta a los corintios (1 Cor 11, 21-22; 11, 34), provocaría finalmente el distanciamiento del rito sacramental propiamente dicho del ágape ${ }^{16}$. Sin embargo, resulta imposible conocer en qué época exacta se produjo dicha separación ni si fue una decisión litúrgica aceptada unánimemente por todas las comunidades cristianas a un mismo tiempo.

La primera descripción detallada de la celebración de una comida litúrgica independiente respecto del tradicional ágape cristiano se encuentra en un texto del apologista romano Justino. Este autor relata que a la eucaristía le precedía una oración común y que el «beso fraternal» marcaba realmente su inicio solemne ${ }^{17}$. «Luego, al que preside a los hermanos, se le ofrece pan y una copa con agua y vino» (I Apol., 65, 3), pues era una práctica antigua beber el vino casi siempre aguado.

[...] y tomándolos él tributa alabanzas y gloria al Padre del universo por el nombre de su Hijo y por el Espíritu Santo, y pronuncia una larga acción de gracias (eucharistía), por habernos concedido esos dones que de El nos vienen. Y cuando el presidente ha terminado las oraciones y la acción de gracias, todo el pueblo presente aclama diciendo: Amén [...] Y una vez que el presidente ha dado gracias y aclamado todo el pueblo, los que entre nosotros se llaman «ministros» o diáconos, dan a cada uno de los asistentes parte del pan y del vino y del agua sobre los que se dijo la acción de gracias y lo llevan a los ausentes ${ }^{18}$.

resultado una cosa obvia para los cristianos de Corinto» (Los orígenes de la moralidad cristiana..., p. 105). Por otro lado, la unión en la comida cristiana aparece descrita con claridad en 1 Cor 12, 27.

14 Vid. M. J. Townsend, «Exist the Agape?...», pp. 357ss., cuyo análisis se centra especialmente en los siguientes pasajes: Hch 2, 42; 27, 33-37; 1 Cor 11, 17-34; Judas, 12 y 2 Pdr 2, 13. Cfr. Además M. Simon, op. cit., p. 41; M. Simon y A. Benoit, op. cit., p. 120; G. Feeley-Harnik. The Lord's Table. Eucharist and Passover in Early Christianity, University of Pennsylvania Press, Philadelphia, 1981; G. Jossa, I cristianesimo antico. Dalle origini al concilio di Nicea, Carocci, Roma, $2007^{2}$ (= Roma, 1997), pp. 55-56. Sobre el rito de la eucaristía en el Nuevo Testamento y, especialmente, en Pablo, vid. sobre todo $\mathrm{H}$. Maccoby, Paul and Helenism, SCM Press/Trinity Press International, London/Philadelphia, 1991, pp. 90-128.

15 A. McGowan, Ascetic Eucharists..., p. 12.

16 G. Jossa, op. cit. p. 56. Cfr. M. Simon y A. Benoit, op. cit., p. 121.

17 Sobre el «beso fraternal» y sus peligrosas «desviaciones lascivas» en las primeras comunidades cristianas, vid. St. Benko, Pagan Rome and the Early Christians, Indiana University Press, Bloomington/ Indianapolis, 1984, pp. 79-102; R. Calatayud Gascó, Beso humano y ósculo cristiano. Dimensiones histórico-teológicas del beso litúrgico, Edicep, Valencia, 2003.

18 Justino, I Apol., 65, 3-5 (trad. D. Ruiz Bueno, Padres apologetas griegos, s. II, BAC, Madrid, $1996^{3}$, p. 256). 
Sabemos por Justino, en efecto, que en la comunidad cristiana de Roma existía en su época la costumbre de enviar el pan eucarístico a la casa de los acólitos enfermos (/ Apol., 67) ${ }^{19}$. Sin embargo, la comida eucarística no podía ser compartida con quienes no estuvieran bautizados, «pues acerca de ello dijo el Señor: No deis lo santo a los perros»20:

Y este alimento se llama entre nosotros «Eucaristía», de la que a nadie es lícito participar, sino al que cree ser verdaderas nuestras enseñanzas y se ha lavado en el baño que da la remisión de los pecados y la regeneración, y vive conforme a lo que Cristo nos enseñó ${ }^{21}$.

Salvo por el significado simbólico y espiritual que adquirieron para los cristianos determinados alimentos y por la inclusión de algunos formalismos rituales, el banquete comunitario o ágape apenas se diferenciaba del symposium o convivium pagano. El banquete típico greco-romano consistía, en primer lugar, en una comida en la que los invitados se sentaban en triclinia dispuestos en forma de $U^{22}$. Después de haber degustado varios platos, se retiraban las mesas y daba inicio la segunda parte de la velada, en la que tenía lugar el symposium propiamente dicho, o fiesta de la bebida. Es en este momento de la reunión en el que se conversaba y se presenciaban diversos entretenimientos lúdicos con copas de vino mezclado con agua. En realidad, tal y como ha resaltado A. McGowan, la última cena de Jesús con sus discípulos más cercanos siguió, según las narraciones neotestamentarias, este mismo esquema, hecho confirmado por las descripciones posteriores del ágape que aparecen en las obras de Tertuliano, escritas en el norte de África a caballo entre los siglos II y III ${ }^{23}$.

Si los relatos que han llegado a nosotros sobre los ágapes cristianos inciden siempre y casi exclusivamente en el pan y el vino, no es porque se careciese de otro tipo de alimentos, sino porque se aludía precisamente a su valor simbólico en las oraciones de la comunidad ${ }^{24}$. De hecho, en el arcosolio de Sabina en la Catacumba de los Santos Pedro y Marcelino (Fig. 1) y en aquel otro en el que aparece la firma de Pomponio Leto, se pueden observar diferentes ánforas y útiles para calentar las bebidas y las fuentes de comida, mientras los comensales muestran una marcada gestualidad ${ }^{25}$. En el primero aparece, además, la in-

19 Tertuliano, además, nos informa en su Ad Martyras de que diversos alimentos se enviaban a los cristianos prisioneros en tiempo de persecuciones. Sobre el particular, vid. A. McGowan, «Food, Ritual...», p. 162.

20 Didaché, 9,5 (D. Ruiz Bueno, Padres apostólicos, BAC, Madrid, 1993, p. 86). Vid. M. Simon, op. cit., p. 41.

21 Justino, I Apol., 66, 1 (trad. D. Ruiz Bueno, Padres apologetas griegos..., p. 257). Cfr. Mt 7, 6; Constituciones Apostólicas, VIII, 11, 11. Vid. Chr. Markschies, op. cit., pp. 170-171.

22 Vid. É. Morvillez, «Klinai ou triclinium? Sur la permanence de l'utilisation du mobilier grec de banquet à l'époque romaine», Mètis. Anthropologie, Philologie, Archeologie, 3, 2005, pp. 57-76.

23 A. McGowan, «Food, Ritual...», p. 154. Cfr. D. Musti, /l simposio nel suo svilupo storico, Laterza, Roma/Bari, $2005^{2}$ (= 2001), pp. 133ss.

24 W. A. Meeks, «Social and Ecclesiastical Life...», p. 165.

25 N. Himmelmann, Typologische untersuchungen an römischen Sarkophagreliefs des 3 und 4 Jahrhunderts n. Chr., Philipp von Zabern, Mainz am Rhein, 1973, p. 54, n. 39; F. Bisconti, «La decoración 
scripción Sabina misce («Sabina mezcla [el vino]»)" ${ }^{26}$. Ahora bien, el pan y el vino, considerados como los alimentos más sencillos que aparecen en el recuerdo de la última cena de Jesús (1 Cor 11, 23-25), Ilevaban consigo un significado intrínseco asociado al ofrecimiento simbólico a la divinidad del sacrificio de un anima ${ }^{27}$. Según Justino, se transformaban, como todo alimento ingerido, en carne y sangre. Sin embargo, dicha metamorfosis no la experimentaban los elementos en sí mismos, sino quienes los recibían ${ }^{28}$. Ciertamente, la comida se iniciaba con una oración sobre un pedazo de pan: «Mientras estaban comiendo, tomó Jesús pan y lo bendijo, lo partió y, dándolo a sus discípulos, dijo...» (Mt 26, 26). Después se repartía entre todos los comensales, quienes lo utilizaban además como cubierto con el que llevar el resto de los alimentos a la boca. Sin duda, el pan fue el elemento más ensalzado en la tradición del ágape cristiano. Aunque ya estaba presente en las ofrendas judías al Templo (Ex 25, 30) y en la comida ritual de Pascua, el pan adquirió para los primeros cristianos un enorme valor simbólico, procedente en buena medida de su carácter ordinario o cotidiano, lo que permitió a los creyentes, según ha apuntado A. McGowan, atribuir a este alimento una gran variedad de significados. Sin duda, el más extendido, y en asociación con el vino, fue su sacralización como cuerpo y sangre de Jesús ${ }^{29}$. En el norte de África a finales del siglo II, según evidencia Tertuliano, existía la costumbre de repartir entre los fieles pedazos de panes bendecidos fuera del banquete eucarístico con el fin de que pudieran consumirse posteriormente ${ }^{30}$ y, hacia mediados del siglo III, Cipriano, obispo de Cartago, describe a ciertos devotos cristianos llevando alrededor de su cuello guardapelos que contenían restos de pan eucarístico ${ }^{31}$. No habría que olvidar, sin embargo, que la inclusión del pan como elemento central de la comida fraternal aporta también el indicio de una costumbre preferentemente urbana, ámbito en el que se desarrolló el primer cristianismo, ya que el pan apenas era consumido en el medio rural ${ }^{32}$.

Aunque el pan y el vino constituían en la mayoría de las comunidades el núcleo en torno al cual giraba el resto del banquete ritual, la variedad e interpretación simbólica de los alimentos podía depender, al igual que en otros ámbitos, de la importancia de la ocasión. Así, por ejemplo, la leche y la miel se incorporaron al

de las catacumbas romanas", en V. Fiocchi Nicolai, F. Bisconti y D. Mazzoleni, Las catacumbas cristianas de Roma. Origen, desarrollo, aparato decorativo y documentación epigráfica (trad. F. M. Romero Pecourt), Schnell and Steiner, Regensburg, 1999, p. 110.

26 Vid. K. M. D. Dunbabin, The Roman Banquet. Images of Conviviality, Cambridge University Press, Cambridge, 2003, p. 178.

27 Vid. J. Klawans, «Interpretating the Last Supper: Sacrifice, Spiritualization, and Anti-Sacrifice», New Testament Studies, 48 (1), 2002, pp. 1-17.

${ }^{28}$ Chr. Markschies, op. cit., p. 171.

29 Vid., por ejemplo, 1 Cor 10, 16-17; 11, 30; Ef 20; Jn 6, 53-58; Ignacio de Antioquía, Epist.

Smyrn., 7, 1. Vid. A. McGowan, Ascetic Eucharists..., pp. 91-95; Idem, «Food, Ritual...», pp. 151-152.

30 Tertuliano, De orat., 19, 1-4. Vid. A. McGowan, «Food, Ritual...», p. 153.

31 Cipriano de Cartago, De laps., 25-26. Vid. A. McGowan, «Food, Ritual...», p. 154.

32 P. Garnsey, Food and Society in Classical Antiquity, Cambridge University Press, Cambridge, 1999, p. 121. 


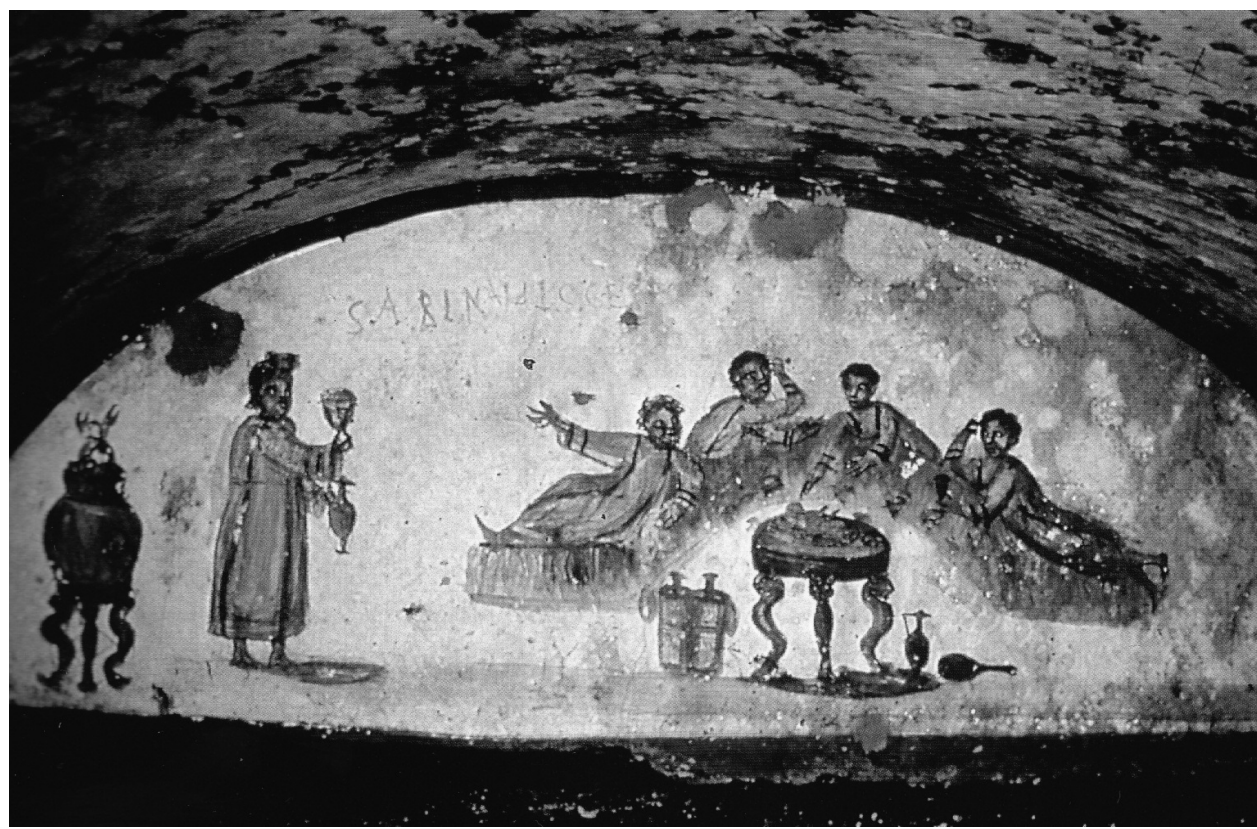

Fig. 1. Catacumba de los Santos Pedro y Marcelino. Arcosolio con escena de Banquete (F. Bisconti, «La decoración...», p. 111).

ágape a finales del siglo II, especialmente durante la celebración de los bautismos. Tales alimentos adquirieron pronto un significado simbólico relacionado con la abundancia y la paz ${ }^{33}$. Incluso en el siglo IV, cuando la comida eucarística había adquirido ya una dimensión ampliamente alegórica, no solamente el pan y el vino fueron acompañados por la leche y la miel, sino que además se añadieron el queso y las aceitunas en la celebración de las ordenaciones episcopales ${ }^{34}$. Respecto a la carne, cuya presencia en la mesa greco-romana era, por su elevado precio, muy escasa y, al mismo tiempo, muy apreciada (razón por la que sólo aparecía en los banquetes que tenían lugar dentro del ámbito de los círculos sociales más exquisitos y en las celebraciones cívicas paganas), no estaba del todo ausente en los ágapes cristianos. Sin duda alguna, la carne sacrificial formaba parte imprescindible de los rituales propios de la religión judía y de los templos paganos. De hecho, tal y como indica el propio Pablo, la producción y distribución de carne podía tener relación directa con el mundo de la religiosidad pagana, ya que, incluso en una buena proporción, la carne que llegaba al mercado procedía de los sac-

33 A. McGowan, Ascetic Eucharists..., pp. 107-115; A. McGowan, «Food, Ritual...», p. 148.

34 Hipólito de Roma, Trad. apost., 6. Vid. P. F. Bradshaw, M. E. Johnson y L. E. Philips, The Apostolic Tradition. An Commentary, Fortress Press, Minneapolis, 2002, pp. 1-17; A. McGowan, Ascetic Eucharists..., pp. 95-107; A. McGowan, «Food, Ritual...», p. 148. 
rificios realizados en los templos ${ }^{35}$. Dada a veces la imposibilidad de conseguir carne que no hubiera pasado previamente por este tipo de rituales idolátricos, el Apóstol llegó a aconsejar a los cristianos que no «preguntasen» (1 Cor 10, 23-27) ${ }^{36}$. Por sus palabras en torno a la carne inmolada de los ídolos, Pablo da a entender que los platos de carne estaban presentes en las comidas cristianas, aunque no exista una claridad absoluta al respecto (1 Cor 8, 1-7). Sabemos por Justino Mártir que los judíos solían criticar el hecho de que «muchos que dicen confesar a Jesús y que se llaman cristianos comen de lo sacrificado a los ídolos y ningún daño afirman que de ahí se les siga» ${ }^{37}$. Además, Ireneo de Lyon atribuye a los cristianos gnósticos, entre otros comportamientos sociales, la costumbre de comer carne ${ }^{38}$. Sin embargo, éstos se distanciaban a su vez de otros grupos cristianos que, como los montanistas, los marcionitas y los encratitas (de cuyas filas salieron, según la tradición, numerosos mártires), se declaraban vegetarianos ${ }^{39}$. Por otro lado, y a pesar de los testimonios literarios (por ejemplo, Jn 21, 13) y artísticos (especialmente, algunos frescos de las catacumbas) (Fig. 2), resulta muy controvertida la presencia del pescado en los banquetes rituales cristianos ${ }^{40}$. Es posible que fuese más aceptable que la carne, pero no existen indicios suficientes como para afirmarlo con seguridad $^{41}$. Curiosamente, en la que se considera la representación más antigua de la última cena, procedente de San Apolinar el Nuevo en Ravenna (ca. 500), aparece Jesús reclinado junto a sus discípulos en torno a una mesa en forma de $U$ con dos pescados en lugar del cordero pascual (Fig. 3) ${ }^{42}$. Salvando, pues, el pan y el vino, que constituían los principales elementos simbólicos en torno a los cuales giraba la comida ritual cristiana, los alimentos que estaban presentes en la mesa durante la primera parte del ágape, eran muy variados y no respondían a ningún ordenamiento que fuese uniforme y común a todas las comunidades cristianas.

35 Los cristianos estaban sujetos, como el resto de la población, a las fluctuaciones que sufría el abastecimiento de los mercados urbanos, aspecto éste que, sin duda, afectaba a la variedad y cantidad de los alimentos que formaban parte de la mesa en los ágapes. De hecho, sabemos que cuando Pablo visitó Corinto en el año 51 se produjo una prolongada escasez de alimentos en la ciudad, cuyo cargo de curator annonae y, por tanto, responsable máximo del abastecimiento a los mercados locales, recaía entonces en Tiberio Claudio Dinippo. Como al resto de los habitantes de la ciudad, esa escasez preocupó al Apóstol, entre otras razones porque podría afectar muy seriamente a la celebración de las comidas en común de los cristianos de Corinto. Sobre este episodio, vid. B. N. Danylak, «Tiberius Claudius Dinippus and the Food Shortages in Corinth», Tyndale Bulletin, 59 (2), 2008, pp. 231-270.

36 Vid. D. E. Smith., op. cit., pp. 288-291.

37 Diálogo con Trifón, 35, 1 (D. Ruiz Bueno, Padres apologetas griegos..., p. 358).

38 Contra las herejías, I, 6, 3; I, 24, 5 y I, 26, 3.

39 A. McGowan, Ascetic Eucharists..., pp. 143-174.

40 A. McGowan, Ascetic Eucharists..., pp. 127-140.

41 En las criptas de Lucina aparece la representación de una pareja de grandes peces asociada a cestos de pan y vasos de vino, lo que no deja lugar a dudas sobre la vinculación de los peces con la celebración eucarística. De hecho, a consecuencia de esta escena, ha surgido en el mundo del arte paleocristiano el concepto de «peces eucarísticos». Vid. F. Bisconti, «La decoración...», p. 111.

42 Vid. A. McGowan, «Food, Ritual...», pp. 150-151; K. M. D. Dunbabin, op. cit., p. 201. 


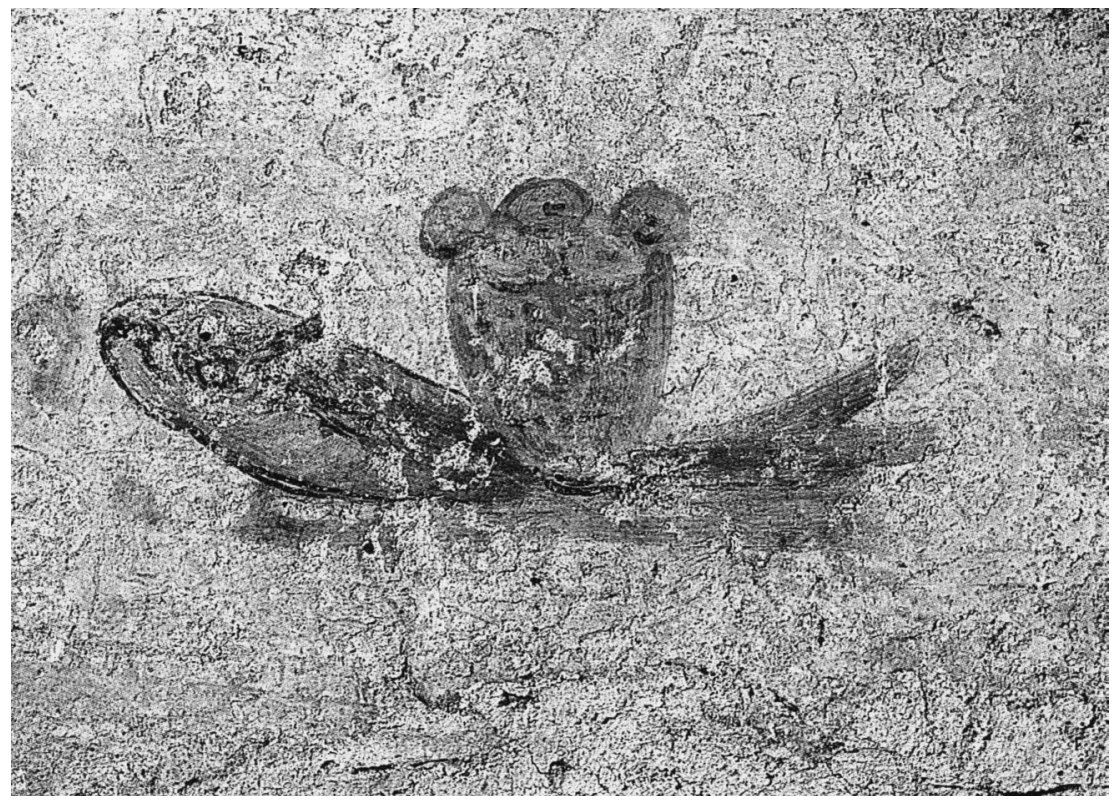

Fig. 2. Catacumba de San Calixto. Criptas de Lucina: cubículo Y (inicios del siglo III). Detalle de «pez eucarístico» (F. Bisconti, «La decoración...», p. 113).

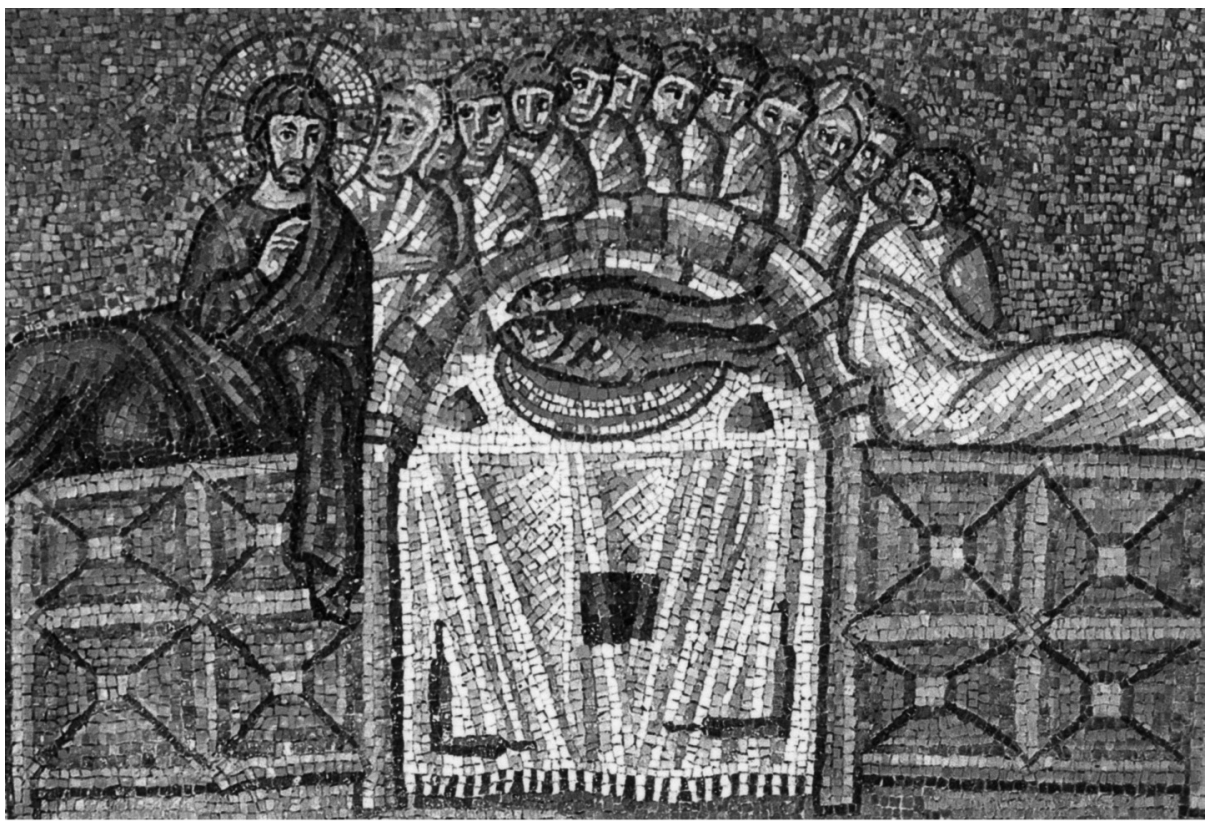

Fig. 3. San Apolinar el Nuevo. Ravenna. Mosaico de la Última Cena (ca. 500). Fotografía: O.G.B. Officina Grafica Bolognese (Bologna, Italia). 
Al igual que sucedía con los symposia paganos, una vez concluida esta primera parte del banquete, se apartaban las mesas y se traía el vino. Seguía, entonces, una ceremonia religiosa, la libación y la ofrenda (vid., por ejemplo, $M c, 14,23$ ). Debe advertirse, no obstante, que algunas comunidades cristianas seguían un orden diferente en el que la copa de vino precedía al pan. El texto más corto de la narración de la última cena, el correspondiente al Evangelio de Lucas (22, 15-19) aseguraba que el vino había precedido a la partición del pan sin que se bebiera una segunda copa de vino después de la cena. Existe un pasaje, además, del propio Pablo en el que éste hace referencia a una "copa de la bendición" antes del "pan que nosotros partimos" (1 Cor 10, 16) $)^{43}$. Ahora bien, en este caso, es muy probable que el Apóstol estuviese describiendo la costumbre particular de la iglesia de Corinto ${ }^{44}$, una costumbre que parece haberse extendido también a otras comunidades, tal y como revela la Didaché. Llama la atención el hecho de que este mismo orden del vino primero y el pan después se encuentra en algunos rollos del Mar Muerto y en la Misná, lo que ha dado pie a que algún autor considerase que esta particular conducta procedía de una tradición judía que, a su vez, y a pesar de las restricciones alimenticias, suponía una clara prueba de la influencia ejercida en el mundo judío (incluyendo el mismo seder de Pascua) por la extendida cultura del symposium grecoromano ${ }^{45}$. De hecho, tal y como advierte Tertuliano (Apol., 39), la alteración del orden en el ágape cristiano al situar el vino al principio fue interpretado como un intento de distanciamiento respecto de los nefandos comportamientos que, a ojos de los cristianos, fomentaban los symposia paganos ${ }^{46}$. En cualquier caso, parece innegable la falta de uniformidad en muchas comunidades cristianas respecto al orden y a los alimentos que fueron seleccionados en los rituales eucarísticos. Llama la atención incluso que algunos grupos cristianos sustituyeran el vino por el agua no sólo en la copa destinada a la celebración eucarística, sino también en las comidas de la comunidad en general, hecho que parece estar vinculado con ciertas restricciones alimenticias y con la aparición de una conducta rigorista y ascética contraria a la abundancia de comida en este tipo de reuniones fraternales ${ }^{47}$.

Si bien es cierto que en el ágape cristiano no está documentado ningún tipo de espectáculo después de la cena, no menos cierto es que la "sobremesa» constituía un momento de alegría en el que se cantaba y se conversaba mientras se bebía vino aguado. Ésta es la descripción, al menos, que ofrece Pablo en su visita a Corinto: al lado de los discursos se entonaban determinados cánticos y se fomentaba la conversación que, en este contexto, se entendía como "enseñanza» (1 Cor 14, 26) ${ }^{48}$. Al igual que las disertaciones filosóficas constituían uno de los ele-

${ }^{43}$ P. F. Bradshaw, «Continuity and Change...», p. 13. 66-97.

44 Vid. E. Mazza, Origins of the Eucharistic Prayer, Liturgical Press, Collegeville (Minn.), 1995, pp.

45 A. McGowan, «The Inordinate Cup: Issues of Orden in Early Eucharistic Drinking», en M. F. Wiles y E. J. Yarnold (eds.), Studia Patristica, XXXV, Peeters, Leuven, 2001, pp. 283-291. Cfr. D. E. Smith, op. cit., pp. 272-273.

46 A. McGowan, «Food, Ritual...», pp. 154-155.

47 McGowan, Ascetic Eucharists..., pp. 67ss. y 143ss. Cfr. P. Garnsey, op. cit., pp. 95-99.

48 M. Klinghardt, loc. cit., pp. 50-57. 
mentos más importantes de la tradición pagana del banquete, los momentos inmediatamente posteriores a la comida en el ágape cristiano suponían una ocasión ideal para el aleccionamiento doctrinal ${ }^{49}$.

Sin duda, alimentamos la fe con las santas palabras — comenta Tertuliano-, construimos la esperanza, modelamos la confianza e igualmente damos solidez a la disciplina al inculcar los preceptos ${ }^{50}$.

Como en el symposium clásico, no hay duda de que en los primeros tiempos del cristianismo, la celebración de banquetes y reuniones religiosas tenía lugar en casas privadas (Figs. 4-5), todavía dentro de la esfera del ágape y en medio de una atmósfera que podría calificarse como de exaltación escatológica en torno al supuesto e inminente regreso del Señor (maranathà, «ven Señor nuestro») ${ }^{51}$. Según se puede apreciar, por ejemplo, en el Evangelio de Lucas, las casas particulares y los oikoi cumplían una función esencial dentro de las primeras comunidades cristianas ofreciendo hospitalidad y cobijo ${ }^{52}$. No era, ni mucho menos, un comportamiento novedoso en el mundo antiguo. De hecho, la hospitalidad (philoxenía) formaba parte de la cultura judía (a veces las propias sinagogas alojaban a viajeros y visitantes) y constituía, por supuesto, una costumbre muy extendida en la sociedad greco-romana ${ }^{53}$. Sólo cuando resultaba imposible acoger en una casa privada a una comunidad que había crecido desmesuradamente, se recurría al alquiler de locales más amplios, parecidos a aquéllos en los que a veces se celebraban los symposia paganos. Por los escritos neotestamentarios, conocemos, por ejemplo, el nombre concreto de diecisiete cristianos de Corinto. Si a este número se añade el de otros componentes de la «casa» es decir, mujer, hijos, esclavos- que podrían haber acompañado al cristiano conocido a la reunión fraternal, se llegaría a una proporción de comensales

49 A. McGowan, «Food, Ritual...», p. 156; D. E. Smith, op. cit., pp. 390-393. Según los escritos neotestamentarios, Jesús mismo veía en estas comidas en común una magnífica ocasión para explicar sus enseñanzas a sus seguidores más cercanos (vid. A. Destro y M. Pesce, L’uomo Gesù..., pp. 112 y 119120).

50 Tertuliano, Apolog., 39, 3 (trad. C. Castillo García, Tertuliano. Apologético. A los gentiles, Gredos, Madrid, 2001, p. 158).

511 Cor 16, 22. Cfr. Ap 22, 20. Vid. G. Jossa, op. cit., p. 56. Sobre este contexto, vid. G. Puente Ojea, Ideología e historia. La formación del cristianismo como fenómeno ideológico, Siglo XXI, Madrid, $1993^{6}$ (= 1974), pp. 191ss. Sobre las domus ecclesiae, vid. H.-J. Klauck, Hausgemeinde und Hauskirche im frühen Christentum, Verlag Katholisches Bibelwerk, Stuttgart, 1981; R. Aguirre, «La casa como estructura base del cristianismo primitivo: las iglesias domésticas», Estudios Eclesiásticos, 58, 1984, pp. 2751; L. M. White, The Social Origins of Christian Architecture, 1. Building God's House in the Roman World: Architectural Adaptation among Pagans, Jews, and Christians, Trinity Press International, Valley Forge (Pennsylvania), 1996 (= The Johns Hopkins University Press, Baltimore, 1990), pp. 103ss. Sobre el origen clásico y veterotestamentario del programa decorativo de las iglesias domésticas cristianas, vid. D. L. Balch, Roman Domestic Art and Early House Churches, Mohr Siebeck, Tübingen, 2008.

52 LC 9, 4-5; 9, 12; 10, 5-7; 11, 5-8; 19, 11; 24, 29-30. Cfr., por ejemplo, Hb 13, 14; Pastor de Hermas, 38, 10 (Mand., 8, 10); 1 Clem 10, 37; 11, 1; 12, 1, 3; Justino, I Apol., 67, 6; etc. Sobre la hospitalidad cristiana, vid. W. A. Meeks, Los orígenes de la moralidad cristiana..., pp. 111-113.

${ }^{53}$ Léase, por ejemplo, la obra De re rustica de Columela (especialmente, I, 5, 7). Sobre el particular, vid. A. Destro y M. Pesce, Forme culturali del cristianesimo nascente, Morcelliana, Brescia, 2005, pp. 91ss. 
que seguramente ya no era posible alojar en un comedor privado de medianas dimensiones. Precisamente, ésa era la situación en la que se encontraba la nutrida comunidad de la ciudad de Éfeso cuando Pablo se vio obligado a alquilar un local para banquetes perteneciente a un tal Tirano $(\text { Hch 19, 9 })^{54}$. Ahora bien, la celebración de este tipo de comidas fraternales dependía normalmente de la generosidad de algún patrono cristiano adinerado que no sólo disponía de una casa con amplios salones, sino que además agasajaba con alimentos y obsequios al resto de la comunidad ${ }^{55}$. Este comportamiento aparece descrito con todo detalle por Hipólito de Roma en su Tradición Apostólica (especialmente en los capítulos 25-29) ${ }^{56}$. Esta especial relación entre los patronos cristianos y sus «clientes» en la comunidad romana venía determinada, según Hipólito, por el apoforetum dentro del contexto de los banquetes cristianos:

[...] Si, lo que se llama en griego un apoforetum, fuese ofrecido de forma comunitaria, acéptalo de él [es decir, del patrono] $[\ldots]^{57}$.
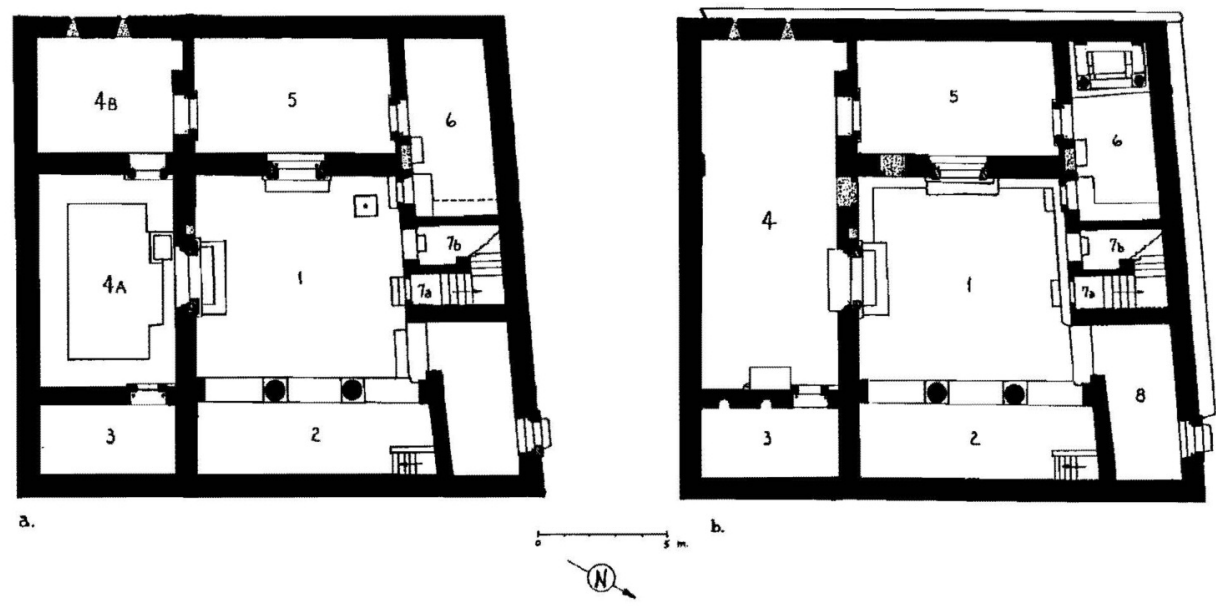

Fig. 4. Dura Europos. Edificio cristiano. Planos reconstruidos de la estructura anterior (a) y posterior como domus ecclesiae (b), según L. M. White, The Social Origins of Social Architecture..., p. 108.

54 Vid. M. Klinghardt, loc. cit., p. 48.

55 Un acercamiento al «evergetismo cristiano» en relación con el concepto de «caridad», en G. Clark, Christianity and Roman Society, Cambridge University Press, Cambridge, $2008^{4}$ (= 2004), pp. 106111.

56 Según Ch. A. Bobertz, «[...] the Christian community, like other groups within Roman society, was dependent on the generosity of its patrons to provide certain characteristic features of Roman social life (such as banquets) and even, at times, subsistence» («The Role of Patron in the Cena Domenica of Hippolitus' Apostolic Tradition», Journal of Theological Studies, 44 (1), 1993, p. 172).

57 Hipólito, Tradición Apostólica, 28, 9-11: [...] Si communiter vero omnibus oblatum fuerit quod dicitur graece apoforetum, accipite ab eo [...]. 


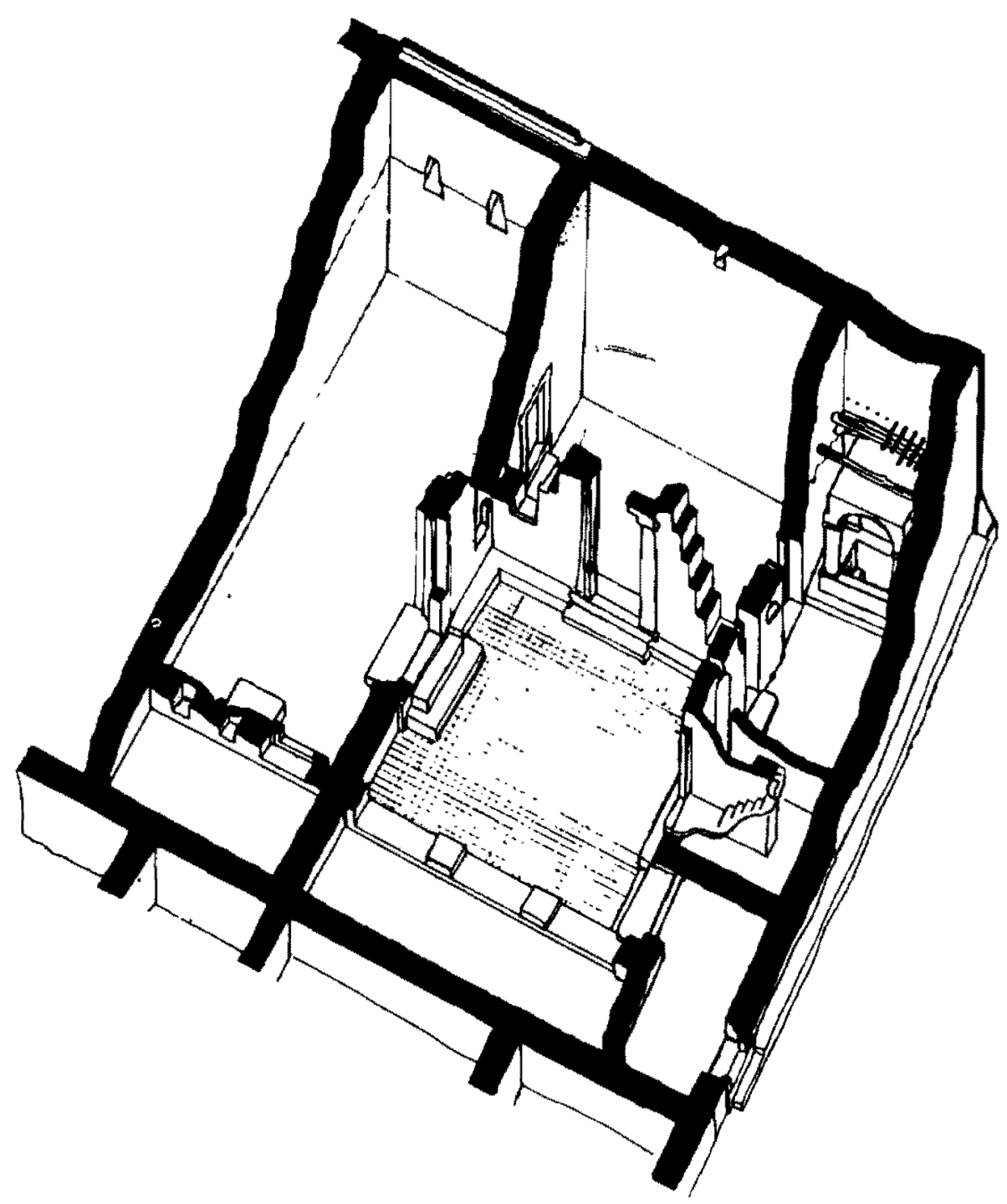

Fig. 5. Dura Europos. Reconstrucción isométrica del edificio cristiano (L. M. White, The Social Origins of Social Architecture..., p. 109).

El término apoforetum se cita tres veces en la cena Trimalchionis del Satyricon de Petronio (40, 56 y 60 ). En todos los casos se refiere a los regalos que los invitados recibieron de su pomposo anfitrión (es decir, del liberto Trimalción). Ciertamente, la comunidad cristiana de Roma contó con fieles de una alta posición socio-económica que, actuando como anfitriones, ofrecían regalos a los 
correligionarios invitados a los banquetes fraternales que tenían lugar en su propia casa ${ }^{58}$. Incluso muchos de estos patronos fueron libertos adinerados que, a pesar de su baja condición social, disponían de medios suficientes como para ofrecer al resto de la comunidad cenas dominicales ${ }^{59}$. A veces los cristianos de mayor estatus social exigían una mayor calidad y cantidad de comida e incluso rechazaban con desdén el apoforetum ofrecido por quienes ocupaban una posición social inferior, trasladando de esta forma, tal y como era normal en los symposia paganos, las distancias jerárquicas que existían en la sociedad civil a las reuniones cristianas ${ }^{60}$. Pablo ya había expresado su disconformidad con este tipo de comportamiento, ya que destruía el espíritu de equidad, fraternidad y unión que debía prevalecer en los ágapes cristianos ${ }^{61}$, lo que no significaba que las diferencias sociales entre los miembros de la comunidad tuvieran que desaparecer por completo: «Hermanos _llegó a afirmar-, permanezca cada cual ante Dios en el estado en que fue llamado» (1 Cor 7 , 24). No obstante, para evitar estas desigualdades y favoritismos, se impuso (al menos en Roma) una rígida estructura en el desarrollo ritual de la Cena Dominica. Según Hipólito, se hacía saber a toda la comunidad que la comida, denominada con la palabra «bendición» (benedictionem), provenía realmente de Dios, razón por la que la recibían de manos del obispo o, en su ausencia, del presbítero o diácono. Además, todos los participantes en el ágape debían tener conciencia de que comían juntos in nomine Dominí2. Aunque el patrono ofrecía el sitio de reunión y los alimentos, él no era el responsable de repartirlos durante la Cena del Señor, prerrogativa que, en efecto, correspondía al obispo o, en su caso, a los sacerdotes de la comunidad ${ }^{63}$. A principios del siglo II, Ignacio de Antioquía insistía en que la presencia del obispo o de los sacerdotes era necesaria para que el ágape pudiera celebrarse ${ }^{64}$. Éste, sin embargo, estaba íntimamente relacionado con la idea de patronazgo reflejada en los banquetes cristianos. Ciertamente, estas comidas comunitarias podrían describirse, según ha sugerido A. McGowan, como «inclusivas» en el sentido de que quienes cenaban

58 En la Tradición Apostólica de Hipólito apararece de forma reiterativa el verbo vocare referido a las invitaciones a la Cena Dominica ofrecida con frecuencia por los patronos cristianos locales: Per omnem uero oblationem memor sit qui offert eius qui illum uocauit; propterea enim depraecatus est ut ingrediatur sub tecto eius (27, 2-6). Cfr. Tradición Apostólica, 28, 4 (qui uocauit uso); 28, 19 (qui uocati sunt). Sobre el particular, vid. Ch. A. Bobertz, loc. cit., pp. 172-173. Sobre esta práctica de los regalos caritativos, vid. J. Riggs, «The Sacred Food of Didache 9-10 and Second Century Ecclesiologies», en C. Jeford (ed.), The Didache in Context. Essays on Its Texts, History, and Transmission, E. J. Brill, Leiden, 1995, pp. 256-283; P. F. Bradshaw, M. E. Johnson y L. E. Philips, The Apostolic Tradition..., pp. 144-152.

59 W. A. Meeks, The First Urban Christians. The Social World of the Apostol Paul, Yale University Press, New Haven/London, 1983, pp. 20-23.

60 Ch. A. Bobertz, loc. cit., pp. 174-175. Cfr. D. E. Smith, op. cit., pp. 386-390.

61 W. A. Meeks, The First Urban Christians..., p. 159; D. E. Smith, op. cit., pp. 406ss. Cfr. J. D'Arms, "The Roman Convivium and the Idea of Equity», en O. Murray (ed.), Sympotica. A Symposium on the «Symposium», Clarendon Press, Oxford, 1990, p. 318.

62 Tradición Apostólica, 28 y 29. Vid. Ch. A. Bobertz, loc. cit., pp. 178-179.

63 Tradición Apostólica, 28, 38. Vid. Ch. A. Bobertz, loc. cit., pp. 181-182.

64 Epist. Smyrn., 8, 1: «[...] Sólo ha de considerarse válida aquella Eucaristía que esté presidida por el obispo o por aquél en quien él mismo delegue» (trad. J. J. Ayán Calvo, Ignacio de Antioquía. Cartas, Ciudad Nueva, Madrid, 1999, p. 177). 
juntos podían pertenecer a clases sociales, géneros y etnias diferentes (traspasando así las barreras impuestas en la época) ${ }^{65}$. Podría afirmarse que, de alguna forma, el ágape nivelaba las diferencias entre los invitados (cfr. Lc 22, 24-27). El propio Jesús ofreció, según el Evangelio de Juan (13, 2-15), un ejemplo de inversión social dentro de la comunidad del banquete al dar inicio a la comida lavando los pies de sus discípulos, un trabajo propio de esclavos ${ }^{66}$. Sin embargo, el alto rango social de quienes participaban en los ágapes podía mantenerse inalterable si, a un mismo tiempo, ocupaban cargos sacerdotales, circunstancia que comenzó a ser muy frecuente ${ }^{67}$. Es muy posible que incluso las mujeres anfitrionas o matronas de la domus en que tenía lugar el ágape desempeñasen un papel destacado. Ahora bien, en este caso concreto, la estructura eclesiástica se mostró muy pronto reacia ${ }^{68}$. Al fin y al cabo, el propio Pablo las había relegado al lugar secundario que, en realidad, venían ocupando tradicionalmente en la sociedad greco-romana (vid., por ejemplo, 1 Cor 14, 33-35) $)^{69}$.

Es muy posible que, como sostiene L. Michael White, la separación de la eucharistía de la comida del ágape propiamente dicho coincidiera con el cambio de lugar en el que este tipo de reuniones fraternales se celebraban ${ }^{70}$. En un momento determinado, las salas de la asamblea comenzaron a desligarse de las domus privadas, dando lugar a la construcción de pequeños edificios destinados exclusivamente al culto religioso ${ }^{71}$. A partir de entonces, las reuniones para el culto dejaron de reflejar el escenario propio de la comida fraternal, a pesar de que la Cena del Señor todavía constituía el centro de la liturgia. En estos momentos, la celebración eucarística comenzó a transformarse en una comida simbólica y ritualizada que poco tenía ya que ver con las comidas en común. Las evidencias arqueológicas y literarias sugieren que este proceso tuvo lugar, aunque con diversas variantes locales en su desarrollo, a lo largo del siglo III72. Podríamos afirmar que Clemente de Alejandría (ca. 203) constituye la primera fuente escrita en la que se refleja ya netamente la separación entre la

65 D. Martin, «Tongues of Angels and Other Status Indicators», Journal of the American Academy of Religion, 59, 1991, pp. 547-589.

66 M. Klinghardt, op. cit., pp. 62-63. Cfr. D. Musti, op. cit., pp. 140ss.; A. Destro y M. Pesce, L'uomo Gesù..., p. 123; D. E. Smith, op. cit., pp. 402, 414-415.

67 A. McGowan, «Food, Ritual...», p. 159.

68 A. McGowan, «Food, Ritual...», pp. 159-160.

69 Sobre este particular, vid., en general, K. Jo Torjesen, Cuando las mujeres eran sacerdotes. El liderazgo de las mujeres en la Iglesia primitiva y el escándalo de su subordinación con el auge del cristianismo (trad. J. Valiente Malla), El Almendro, Córdoba, 1996 (= Harper, San Francisco, 1993); K. E. Korley, Private Women, Public Meals. Social Conflict in the Synoptic Tradition, Hendrickson, Peabody (Mass.), 1993; T. Berger, Women's Way of Worship. Gender Analysis and Liturgical History, Liturgical Press, Collegeville (Minn.), 1999.

70 L. M. White, «Regulating Fellowship in the Communal Meal: Early Jewish and Christian Evidence», en I. Nielsen y H. S. Nielsen (eds.), Meals in a Social Context. Aspects of the Communal Meal in the Hellenistic and Roman World, Aarhus University Press, Aarhus/Oxford, 1998, p. 180.

71 Vid. especialmente L. M. White, The Social Origins of Christian Architecture..., pp. 119ss.

72 Vid., no obstante, las sugerentes reflexiones de Kr. Sessa, «Domus ecclesiae: Rethinking a Category of ante-pacem Christian Space», Journal of Theological Studies, 60 (1), 2009, pp. 90-108. 
eucaristía y el ágape (Paed., 2, 1) ${ }^{73}$. Y, a su vez, a mediados del siglo III, las cartas de Cipriano y la obra siria conocida como Didascalia ofrecen, a pesar de sus diferencias regionales, una descripción espacial cuidadosamente articulada del edificio de la iglesia al margen de las domus privadas ${ }^{74}$. De hecho, en el siglo IV, las comidas rituales domésticas tenían ya muy poco en común con las reuniones eucarísticas de toda la comunidad cristiana. Los elementos de aleccionamiento doctrinal fueron paulatinamente saliendo del espacio reservado al ágape comunitario. A medida que se fueron desarrollando los formalismos propios de las reuniones litúrgicas cristianas, fue disminuyendo la comida en favor de la palabra y el discurso ${ }^{75}$. Incluso en el Concilio de Laodicea (finales del siglo IV), en la Frigia Pacatiana, se prohibía ya la celebración de ágapes en el interior de las iglesias:

No es decente que se celebre el ágape en las iglesias del Señor, ni se coma dentro de ellas, ni se monten triclineos ${ }^{76}$.

Tan sólo un pequeño número de fieles continuó en esa época reuniéndose en casas privadas para celebrar cenas en las que podían incluirse algunas oraciones y ciertos rituales específicos de carácter religioso ${ }^{77}$. Incluso comenzaron a proliferar en esta época capillas en el interior de las villae pertenecientes a potentiores cristianos (Fig. 6). Y tampoco habría que ignorar que las comidas en común que fueron surgiendo en la esfera del emergente movimiento monástico constituyeron, a su vez, otra forma selectiva y marcadamente ascética del antiguo banquete fraternal cristiano ${ }^{78}$.

En realidad, era tal la relación que en origen existía entre el symposium pagano y la comida fraternal cristiana, que los valores más importantes que definían al banquete clásico (es decir, la paz, la concordia y la amistad) podemos también encontrarlos presentes en las virtudes que debían inspirar el ánimo de los cristianos que asistían a los ágapes comunitarios ${ }^{79}$. En la Didaché se estipula lo siguiente:

73 D. E. Smith, op. cit., p. 429.

74 L. M. White, The Social Origins of Christian Architecture..., pp. 123-126; Idem, Texts and Monuments of the Christian Domus Ecclesiae in Its Enviroment, Trinity Press International, Valley Forge (Pennsylvania), esp. $\mathrm{n}^{\mathrm{os}} 16$ y 18. Cfr. D. E. Smith, op. cit., pp. 429-431.

75 Según A. McGowan, «sermons and catechesis continued or expanded, as did the actual prayers and blessings, almost in inverse proportion to the size and scope of the meal itselft» («Food, Ritual...», p. 157).

${ }^{76}$ Concilio de Laodicea, 28. Vid. Ch. J. Hefele, A History of the Councils of the Church, from the Original Documents, II. A.D. 326 to A.D. 429 (transl. H. Nutcombe Oxenham), T. \& T. Clark, Edinburgh, 1896, pp. 315-316 (= Ch. J. Hefele y H. Leclercq, Histoire des conciles d'après les documents originaux, tome I, deuxième partie, Letouzey et Ané, Paris, 1907, p. 1015); Chr. Markschies, op. cit., p. 173.

77 Vid. K. Bowes, Private Worship, Public Values, and Religious Change in Late Antiquity, Cambridge University Press, Cambridge, 2008, p. 50.

78 A. McGowan, «Food, Ritual...», pp. 160-161.

79 M. Klinghardt, loc. cit., p. 58-60. 


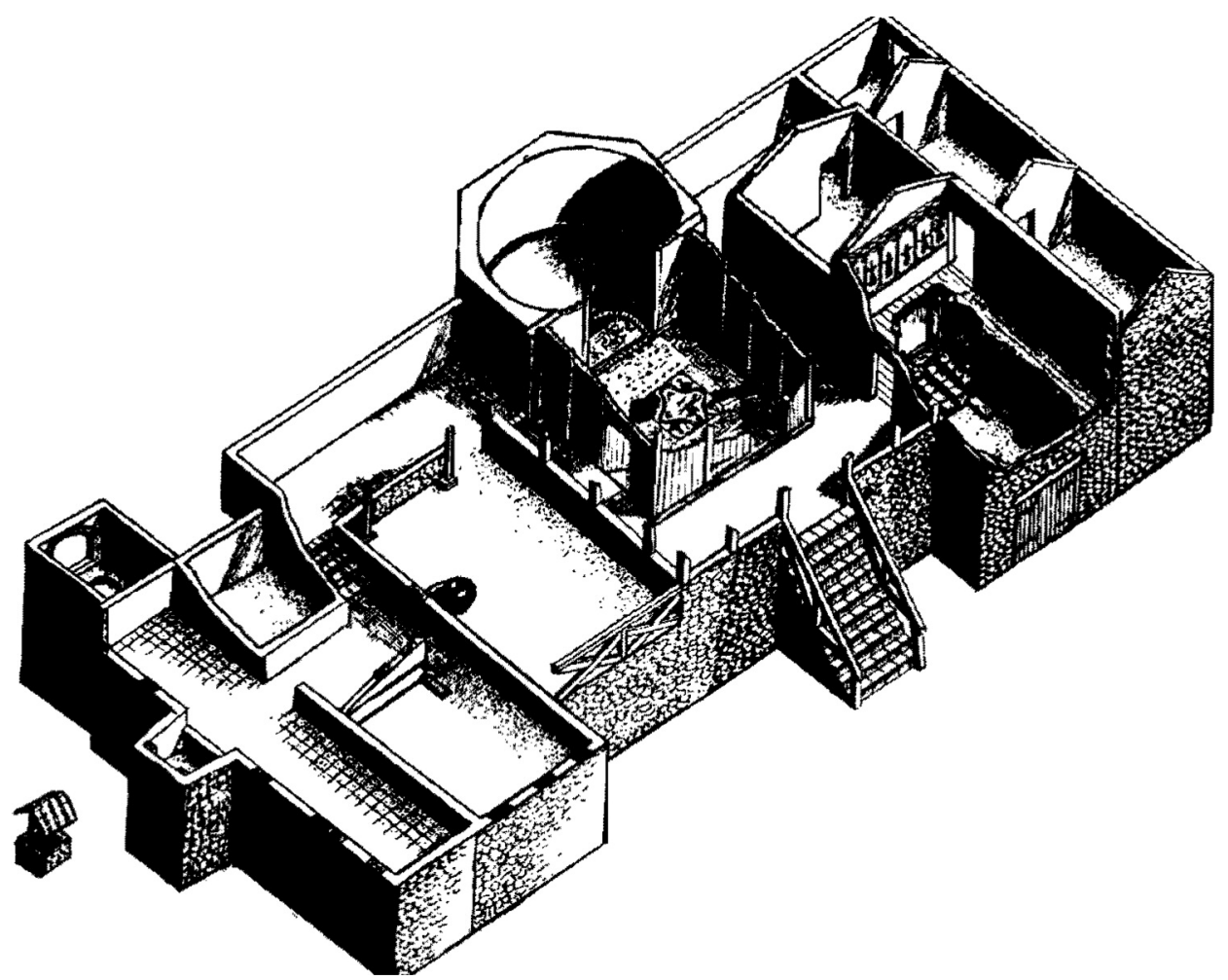

Fig. 6. Reconstrucción isométrica de la villa romana de Lullingstone (Britannia) con una capilla cristiana en su interior (L. M. White, The Social Origins of Social Architecture..., p. 116).

En el día del Señor, cuando os reunáis, partid el pan y dad gracias después de que hayáis dado a conocer vuestras faltas para que vuestra ofrenda sea pura. ¡Pero todo aquel que tenga una disputa con su prójimo no debe reunirse con vosotros hasta que se hayan reconciliado, para que así vuestro sacrificio no se vea profanado! ${ }^{80}$.

Para la incipiente jerarquía cristiana la concordia en el banquete resultaba, pues, tan esencial que la misma comida en común recibía el nombre de ágape, es decir, «amor»81. Sin embargo, estas reuniones y banquetes de la comunidad cristiana fueron vistos con recelo por los paganos ${ }^{82}$. Por su supuesta afinidad, algunos consideraban que la eucaristía no era más que una burda imitación de los

80 Didaché, XIV, 1-2.

81 Judas, 12; Ignacio de Antioquía, Epist. Smyrn., 8, 2: «No es lícito bautizar ni celebrar un banquete de amor $(\alpha \downarrow \alpha \eta \nu)$ sin el obispo». Cfr. Tertuliano, Apolog., 39, 16.

82 V. E. Grimm, From Feasting to Fasting, the Evolution of a Sin. Attitudes to Food in Late Antiquity, Routledge, London/New York, 1996, pp. 55-56; A. McGowan, «Food, Ritual...», p. 158; D. Musti, op. cit., p. 135. 
misterios de Mitra, razón por la que Justino Mártir se apresuró a dar la vuelta a tal reproche afirmando que, muy al contrario, "esta costumbre ha sido imitada por los perversos demonios en los misterios de Mitra»83. Además, según afirman los apologistas, corrían rumores de que en las reuniones cristianas clandestinas y en los ágapes se producían orgías incestuosas y se practicaban el infanticidio y el canibalismo ${ }^{84}$.

Se rumorea que somos los más criminales por el rito de infanticidio, por el convite hecho con él y por el incesto cometido tras el banquete, que — según dicen- facilitan los perros derribando las luces, es decir, convertidos en alcahuetes de tinieblas, con el fin de ocultar los desenfrenos impíos ${ }^{85}$.

Tertuliano, como el resto de los apologistas cristianos de la época, se esforzó en demostrar la falsedad de estos prejuicios anticristianos ${ }^{86}$, comenzando por resaltar la moderación de los alimentos en el banquete cristiano, tantas veces negada y transformada en opulencia por los paganos:

Nuestra cena da razón de sí por su nombre: se llama lo mismo que el amor entre los griegos. Sea cual fuere el gasto que produce, es una ganancia hacer un gasto por motivos de piedad, ya que los pobres y los que se benefician de este refrigerio no se asemejan a los parásitos de vuestra sociedad, que aspiran a la gloria de esclavizar su libertad a instancias del vientre, en medio de gracias groseras, sino porque ante Dios tiene más valor la consideración de los que tienen pocos medios. Si es honroso el motivo del banquete, valorad, teniéndoos a la causa, el modo en que se desarrolla: lo que se hace por obligación religiosa no admite ni vileza ni inmoderación. No se sientan a la mesa antes de gustar previamente la oración a Dios; se come lo que toman los que tienen hambre; se bebe en la medida en que es beneficioso a los de buenas costumbres [...] Después de lavarse las manos y encender las velas, cada cual según sus posibilidades, tomando inspiración en la Sagrada Escritura o en su propio talento, se pone en medio para cantar a Dios: de

83 Justino, I Apol., 66, 4. Y muy bien podría haber sido así, pues la comida ¿iniciática? de pan y vino en el culto a Mitra se originó realmente después del cristianismo, aunque es muy improbable que estas prácticas derivasen históricamente la una de la otra, pues los adeptos de ambos grupos no llegaron a solaparse. De hecho, los misterios de Mitra florecieron entre los años 140 y 312 d. C. en Roma y en las fronteras militares del Imperio romano y tuvieron incidencia especialmente entre los oficiales y funcionarios del ordo equester, por un lado, y los esclavos y libertos imperiales, por otro. Vid. R. Merkelbach, Mithras, Hain, Königstein, 1984, pp. 189-190 y Chr. Markschies, op. cit., pp. 171-172.

84 Justino, I Apol., 26, 7; Minucio Félix, Oct., 9, 5ss.; 8, 4; 8, 9; 10, 1; 28, 2ss.; Tertuliano, Apolog., 7, 1ss.; 39, 14; De spect., 13, 4; Ad nat., 1, 23ss.; 15; Orígenes, Contr. Cels., 6, 27. Vid. J. P. Waltzing, «Le crime rituel reproché aux chrétiens du II siècle», Musée Belge. Revue de Philologie Classique, 25, 1925, pp. 209-238; St. Benko, op. cit., pp. 54-78; M. J. Edwards, «Some Christians Immoralities», Ancient Society, 23, 1992, pp. 71-82; A. McGowan, «Eating People: Accusations of Cannibalism against Christians in the Second Century», Journal of Early Christian Studies, 2, 1994, pp. 413-442; A. A. Nagy, "La forme originale de l'accusation d'anthropophagia contre les chrétiens, son dévelopment et les changements de sa représentation au IIe siècle», Revue des Études Augustiniennes, 47, 2001, pp. 223-249; W. H. C. Frend, «Persecutions: Genesis and Legacy», en M. M. Mitchell y F. M. Young (eds.), The Cambridge History of Christianity, 1. Origins to Constantine, Cambridge University Press, Cambridge, 2006, p. 509; G. Clark, op. cit., p. 19. Cfr. E. Sánchez Salor, Polémica entre cristianos y paganos a través de los textos. Problemas existenciales y problemas vivenciales, Akal, Madrid, 1986, pp. 421-422 y 444-454.

85 Tertuliano, Apolog., 7, 1 (trad. C. Castillo García, op. cit., p. 76).

86 Chr. Markschies, op. cit., p. 172. 
ahí puede deducirse de qué modo había bebido. Igualmente la oración pone fin al banquete. Entonces se marchan agrupados, no en catervas de malhechores, ni en pandillas de libertinos, sino con tenor modesto e intachable, como es propio no de quienes han tomado un banquete, sino una enseñanza ${ }^{87}$.

No cabe duda de que en este pasaje Tertuliano pretendía marcar la enorme distancia moral que, desde la visión de un devoto cristiano, existía entre el symposium pagano y el ágape celebrado por la comunidad cristiana ${ }^{88}$. De hecho, en su polémica en torno a la depravación de las costumbres paganas, también Clemente de Alejandría contrasta la opulencia de los banquetes mundanos con la sobriedad cristiana del ágape ${ }^{89}$. Pero denuncia, al mismo tiempo, la imitación de los excesos paganos que algunos cristianos hacían en sus mesas. En este sentido, reprocha las exquisiteces y manjares deliciosos que algunos fieles cristianos de Roma exhibían ostentosamente y devoraban en sus comidas cotidianas:

[...] pájaros de Phasis, gallinas salvajes de Egipto, pavos de Media [...] rodeados del murmullo de cazuelas burbujeantes y ocupados toda su vida con el almirez, estos glotones quieren consumirlo todo, como el fuego a la madera ${ }^{90}$.

Él que, según afirmaba, se alimentaba de forma muy moderada, no podía sino advertir que «si algunos, con lengua irreverente, osan llamar ágape a esos festines que exhalan aromas de asados y salsa, se equivocan»"11. Así pues, al igual que ocurría con los banquetes paganos, las comidas fraternales cristianas podían ofrecer también oportunidades para la ostentación de la riqueza, provocando así cierta alteración de la cohesión de la comunidad ${ }^{92}$. Consciente de este peligro, Hipólito aconseja a los fieles cristianos mantener una buena conducta durante los ágapes, quizás porque ésta no siempre era intachable:

Cuando comáis y bebáis, hacedlo mesuradamente, y no hasta el hartazgo y la ebriedad a fin de que no se burle de vosotros aquél que os invitó y no se entristezca por vuestra turbulencia. Haced, en cambio, que se sienta digno de que los santos entren en su casa ${ }^{93}$.

No cabe duda de que este pasaje aporta un detalle de realismo del que carece la mayoría de las otras fuentes cristianas en las que el supuesto comportamiento ideal de la comunidad cristiana en sus reuniones religiosas contrastaba con los excesos y desenfrenos cometidos por los paganos en sus symposia ${ }^{94}$.

87 Tertuliano, Apolog., 39, 16-20 (trad. C. Castillo García, op. cit., pp. 161-162).

88 Vid. V. E. Grimm, op. cit., pp. 116-120.

${ }^{89}$ Clemente de Alejandría, Paed., II, 1, 3. Vid. V. E. Grimm, op. cit., p. 100.

90 Clemente de Alejandría, Paed., II, 3, 2 (trad. Chr. Markschies, op. cit., p. 173). Cfr. Tertuliano, De ieiunio, 17.

91 Clemente de Alejandría, Paed., II, 4, 3 (trad. Chr. Markschies, op. cit., p. 173).

92 Clemente de Alejandría, Paed., II, 1, 6-7. Vid. V. E. Grimm, op. cit., p. 101.

93 Tradición Apostólica, 28, 1-5. Cfr. 28, 18-20; 28, 25-26; 28, 30; 28, 37; 29, 4.

94 Vid. Ch. A. Bobertz, loc. cit., pp. 176-177. 
El hecho de que el banquete funerario aparezca muy difundido en el arte de las catacumbas, puede estar igualmente muy relacionado con las antiguas comidas funerarias paganas (Fig. 7$)^{95}$. Incluso es posible que, como ha sostenido V. E. Grimm, para algunos nuevos conversos al cristianismo el ágape reemplazase de alguna forma a los banquetes paganos de las sodalitates y de las tradicionales asociaciones funerarias romanas ${ }^{96}$. Ya desde la época de las persecuciones generales contra los cristianos dentro del Imperio romano, la evocación del martirio tendió a convertirse en una especie de devoción a la muerte heroica a causa de la fe. De hecho, tal y como ha afirmado A. McGowan, «los cristianos estaban acostumbrados a cenar con la muerte» desde una época muy temprana, tal y como atestiguan las pinturas de las catacumbas del siglo $\mathrm{III}^{97}$. Es cierto que no siempre resulta fácil descifrar en toda su extensión este tipo de escenas de banquete ${ }^{98}$, cuya muestra más antigua podría situarse a principios del siglo III en el célebre y discutido hipogeo de los Aurelios (Fig. 8) ${ }^{99}$. Sin embargo, parece innegable que evocan a las antiguas comidas funerarias helenísticas que, con su carácter sacrificial, lúdico y propiamente funerario, tanto eco tuvieron en la cultura romana ${ }^{100}$. En este sentido, al igual que sucedía en la tradición greco-romana, el imaginario figurativo cristiano presente en las catacumbas refleja a un mismo tiempo un sentido público o cívico, estrechamente vinculado a la comunidad (como es el caso de la pintura del ático del mausoleo de Clodio Hermes en las catacumbas de San Sebastián, Fig. 9), y otro de carácter más familiar e íntimo (como puede observarse en los frescos del cementerio de los Santos Pedro y Marcelino, Fig. 1) ${ }^{101}$. Por ello, la mayor parte de los investigadores ha atribuido a las escenas de ágapes y refrigeria que aparecen en las pinturas de las catacumbas y en los relieves de los sarcófagos paleocristianos (vid. Figs. 10-11) un significado exclusiva y propiamente funerario ${ }^{102}$.

95 Vid. R. M. Jensen «Toward a Christian Material Culture», en M. M. Mitchell y F. M. Young (eds.), The Cambridge History of Christianity, 1. Origins to Constantine, Cambridge University Press, Cambridge, 2006, p. 576.

96 V. E. Grimm, loc. cit., p. 244, n. 35.

97 A. McGowan, «Food, Ritual...», p. 162. En la relación del ágape cristiano con la muerte y en la simbiosis que en el ámbito del banquete se produce entre los elementos de convivencia y tristeza, podemos descubrir también ciertos paralelismos con el simposio socrático-platónico. Sobre el particular, vid. el agudo análisis de G. Steiner, «Due cene. Le "ultime cene" di Socrate e di Gesù di Nazaret in una straordinaria analisi interpretativa. II racconto del Convito e quello del Vangelo di Giovanni», Micromega, 3, 1996, pp. 97-125.

98 Vid. E. Jastrzebowska, «Les scènes de banquet dans les peintures et scultures des III et IVe siècles», Recherches Augustiniennes, 14, 1979, pp. 3-90.

99 F. Bisconti, «L'ipogeo degli Aureli in viale Manzoni: un esempio di sincresi privata», Augustinianum, 25, 1985, pp. 885-903.

100 F. Bisconti, «La decoración...», p. 109; K. M. D. Dunbabin, op. cit., pp. 187ss.

101 F. Bisconti, «La decoración...», p. 109; K. M. D. Dunbabin, op. cit., pp. 177ss.

102 Vid., por ejemplo, P.-A. Février, «A propos du repas funéraire. Culte et sociabilité. "In Christo Deo pax et concordia sit convivio nostro"», Cahiers Archéologiques, 26, 1977, pp. 29-45; Idem, "Le culte des morts dans les communautés chrétiennes durant le III siècle», en Atti del IX Congresso Internazionale di Archeologia Cristiana, Pontificio Istituto di Archaeologia Cristiana/École Française de Rome, Città del Vaticano/Roma, 1978, I, pp. 211-274. 


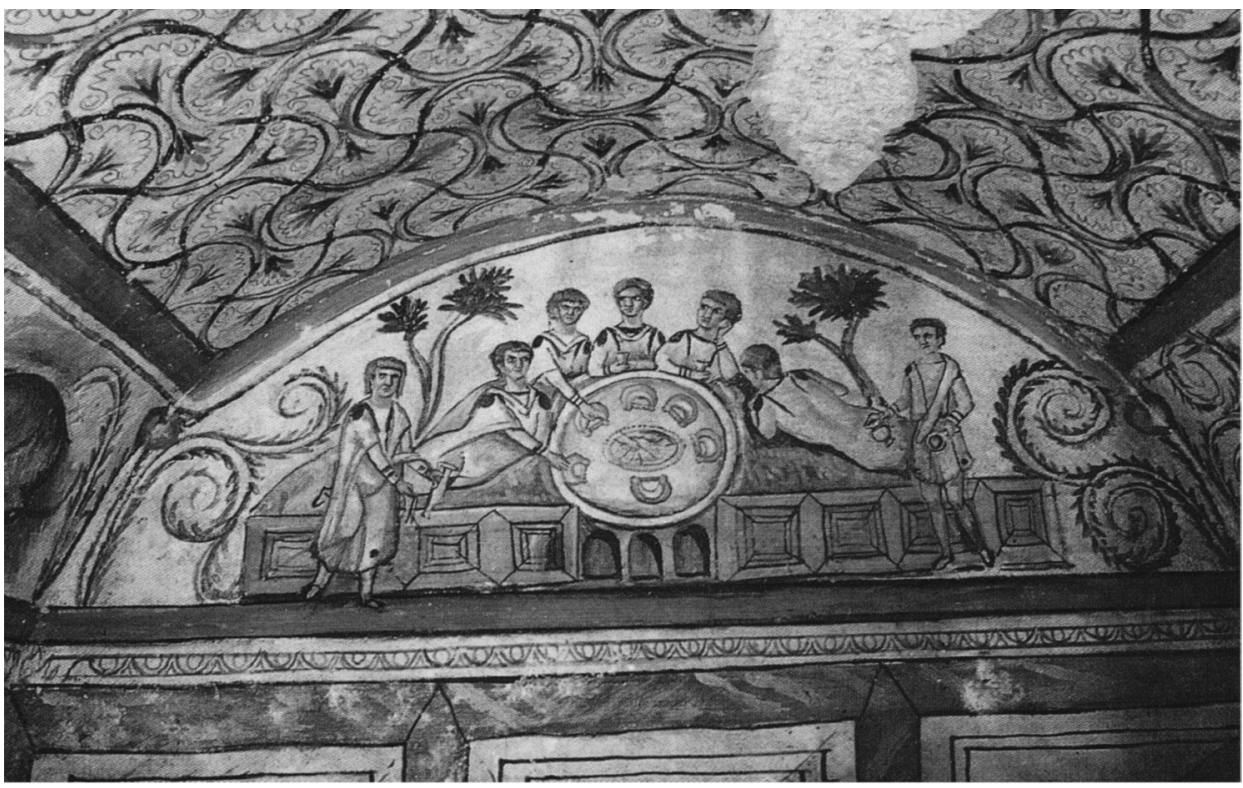

Fig. 7. Constanza, Rumania (antigua Tomis). Tumba de banquete sobre stibadium. Mediados del siglo IV (K. M. D. Dunbabin, op. cit., Plate xiii).

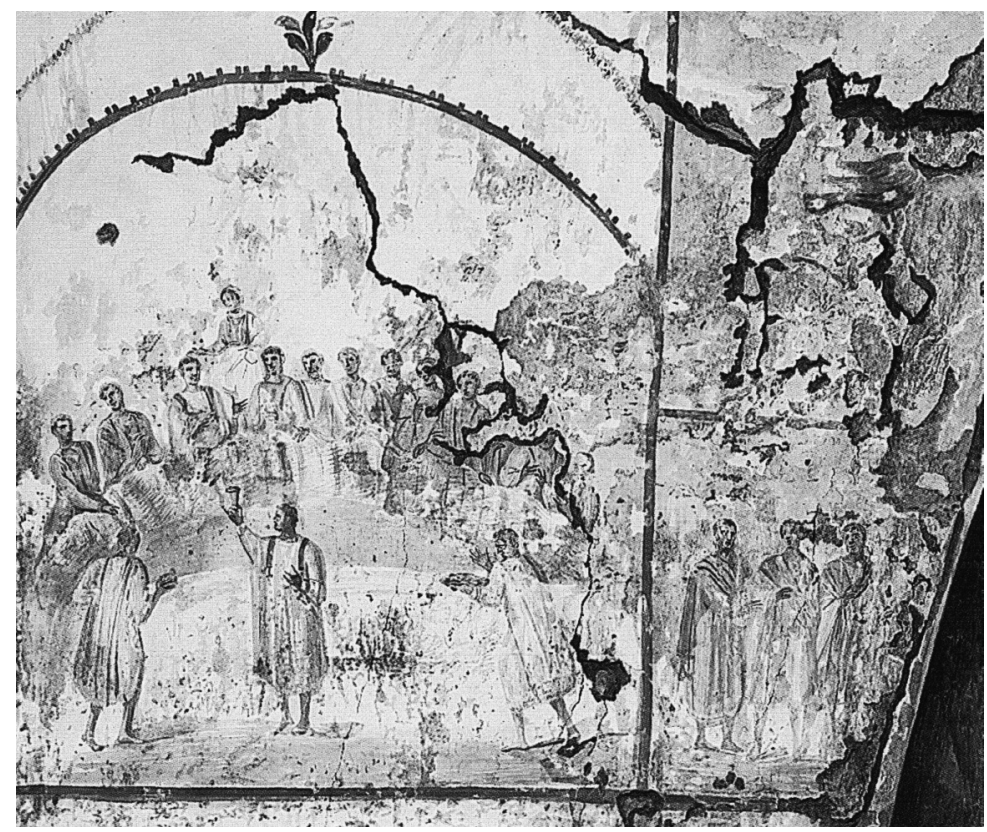

Fig. 8. Hipogeo de los Aurelios en el vial Manzoni.

Escena de banquete (F. Bisconti, «La decoración...», p. 109). 


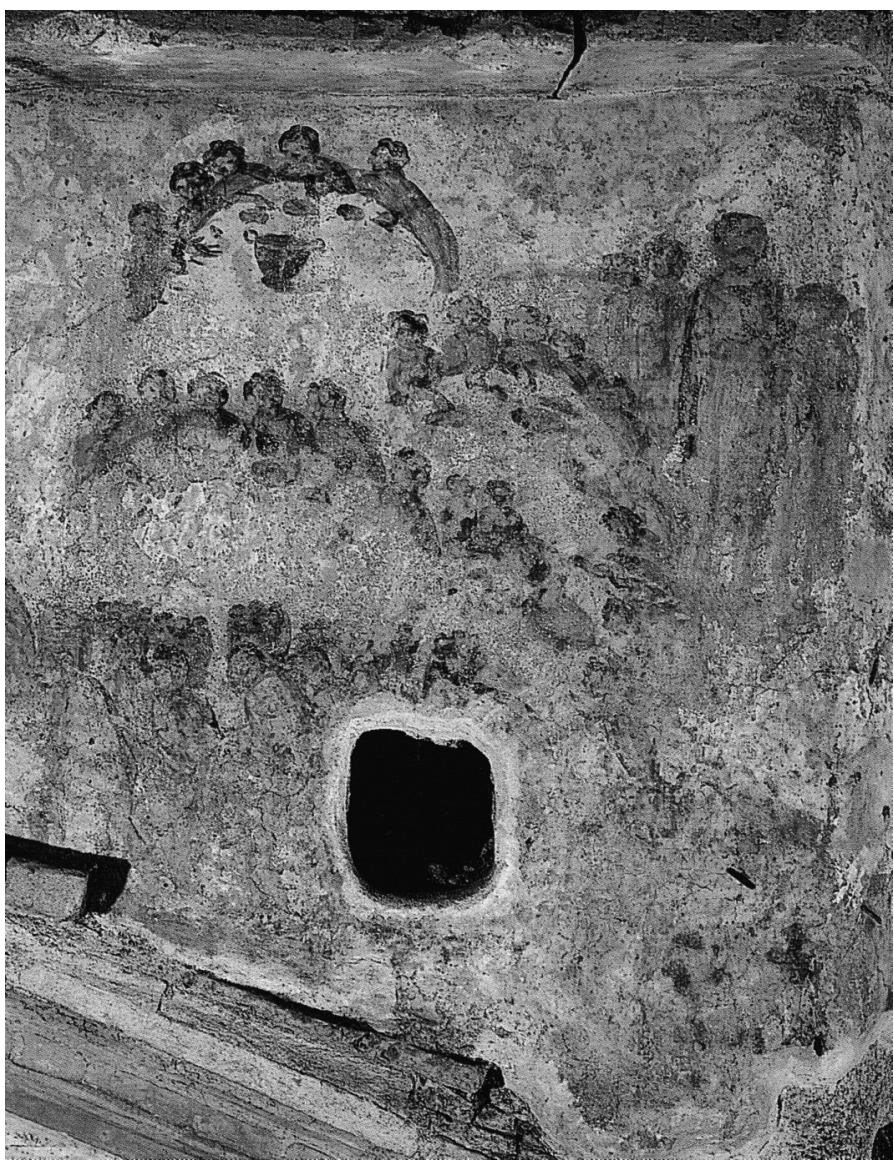

Fig. 9. Complejo de San Sebastián. Mausoleo de Clodio Hermes. Decoración del ático con escenas de banquete (F. Bisconti, «La decoración...», p. 110).

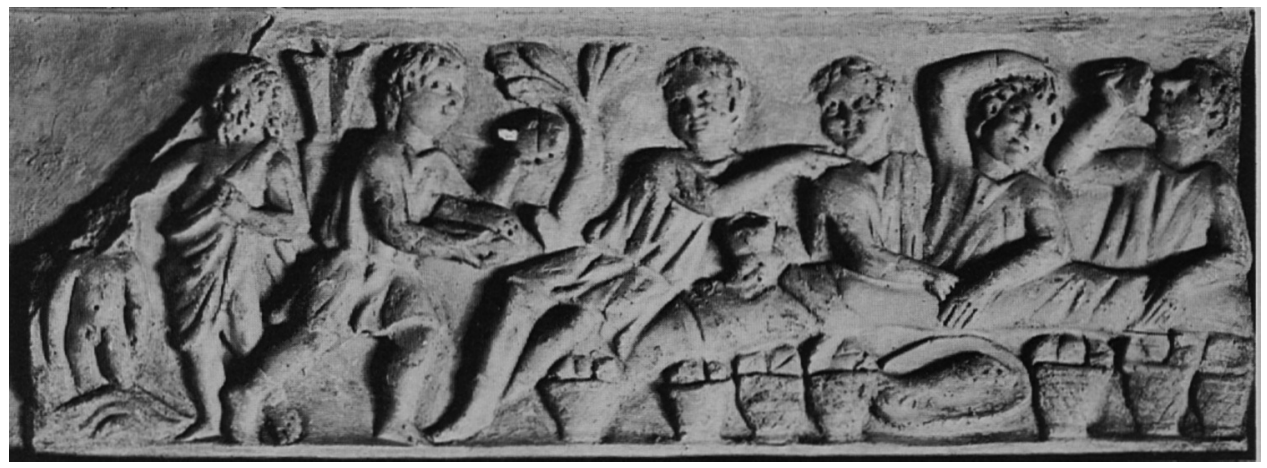

Fig. 10. Fragmento de sarcófago. Museo Pio Cristiano. Vaticano (N. Himmelmann, op. cit., Tafel 47b). 


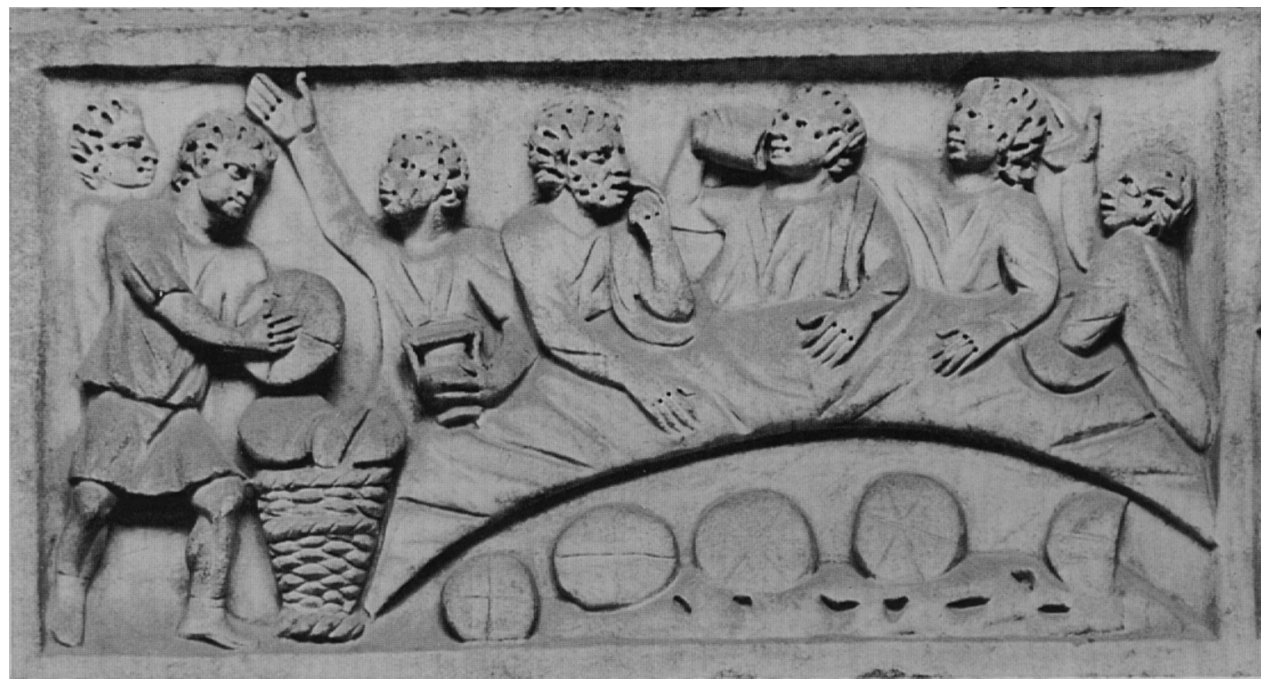

Fig. 11. Detalle del sarcófago de Baebia Hertofile. Museo Nazionale Romano. Roma (N. Himmelmann, op. cit., Tafel 47c).

Sin embargo, no pueden pasarse por alto las implicaciones simbólicas que a veces se detectan en estas representaciones de banquetes en contexto funerario. Así, por ejemplo, en el ágape pintado en una de las capillas de los Sacramentos de las catacumbas de San Calixto aparece en la escena una singular impositio manuum sobre un trípode con un pan y un pez (Figs. 12-13), motivo repetido en la misma capilla, aunque, esta vez, añadiendo siete cestos de pan (Fig. 14) ${ }^{103}$. Si a estas representaciones de evidentes gestos de bendición se unen otras escenas de banquete en las que, dentro del mismo contexto funerario, aparecen figuras en levitación, habrá que concluir que muchas de estas pinturas deseaban evocar de forma simbólica el «banquete celestial» que le esperaba al devoto cristiano después de la muerte ${ }^{104}$. Sin renunciar a las imágenes iconográficas asociadas a la práctica funeraria cristiana, en el cementerio de los Santos Pedro y Marcelino aparece representada una escena de banquete ambientada en un escenario en plein air ${ }^{105}$. En efecto, la suspensión en el aire de ciertas imágenes y la atmósfera que se respira en torno a ellas, transportan a quien las visualiza a un nivel simbólico en el que cabría situar el concepto del «convite celestial». Son los casos, sin duda alguna, de la conocida coena celestis del hipogeo de Vibia (ca. 350), donde aparece un animado banquete ambientado en los Campos Elíseos (Fig. 15) ${ }^{106}$, o

103 F. Bisconti, «La decoración...», p. 111.

104 K. M. D. Dunbabin, op. cit., p. 177. Sobre el «banquete futuro» en Jesús según los Sinópticos, vid. A. Destro y M. Pesce, L'uomo Gesù..., pp. 124-126.

105 Vid. F. Bisconti, «Sulla concezione figurativa dell'habitat paradisiaco: a proposito di un affresco romano poco noto», Rivista di Archeologia Christiana, 66, 1990, pp. 25-80.

106 K. M. D. Dunbabin, op. cit., pp. 189-191. 
del citado ágape del hipogeo de los Aurelios (Fig. 8) ${ }^{107}$, pero también de la famosa lápida dedicada a Criste por su padre Cristor en las catacumbas de Domitila, pues en ella aparece la pequeña difunta situada en un paraíso representado por medio de escasos pero eficaces recursos, como son las palomas noéticas y la pose expansis manibus, mientras su padre bebe y ofrece un último bocado a un perrito, quizás muy estimado por su dueña (Fig. 16) ${ }^{108}$. A través, en definitiva, de este motivo iconográfico, se trataba de proyectar el ágape terrenal en una esfera celestial y edénica ${ }^{109}$.

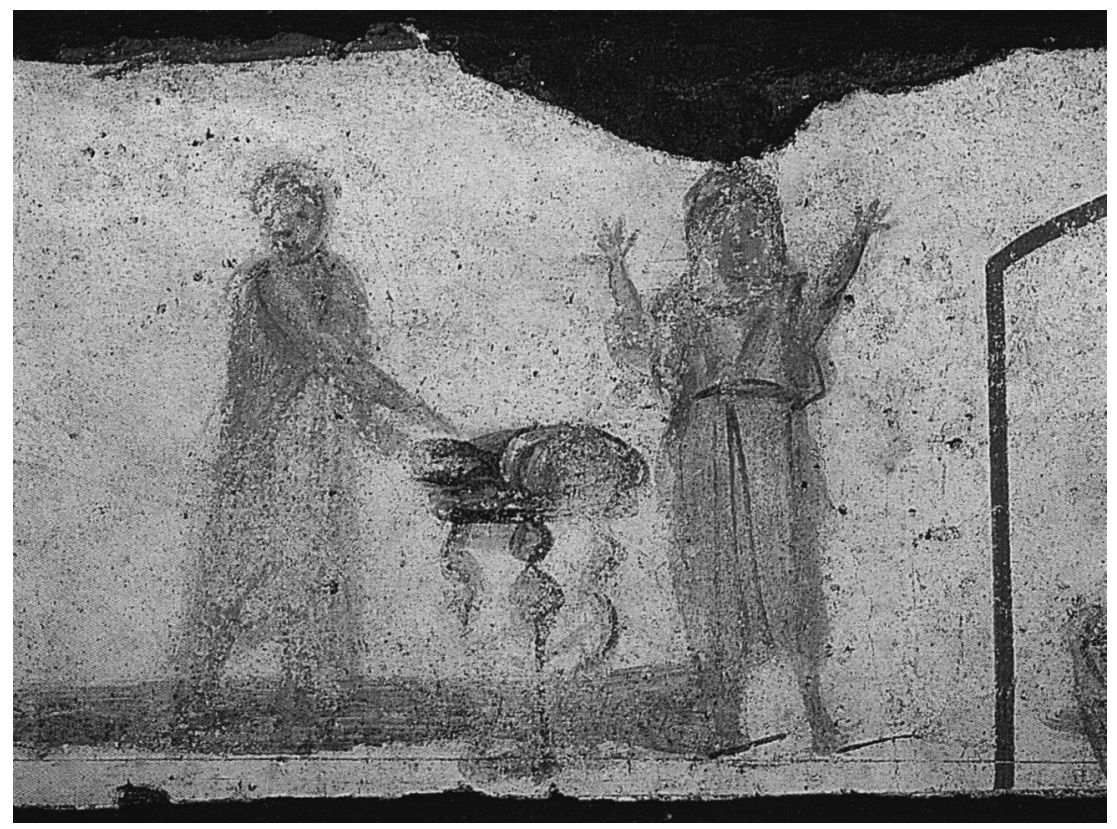

Fig. 12. Catacumba de San Calixto. Cubículo A3 de los Sacramentos con escena de impositio manuum (F. Bisconti, «La decoración...», p. 112).

107 F. Bisconti, «La decoración...», pp. 109-110.

108 F. Bisconti, «La decoración...», pp. 111-112.

109 F. Bisconti, «La decoración....», p. 110. 


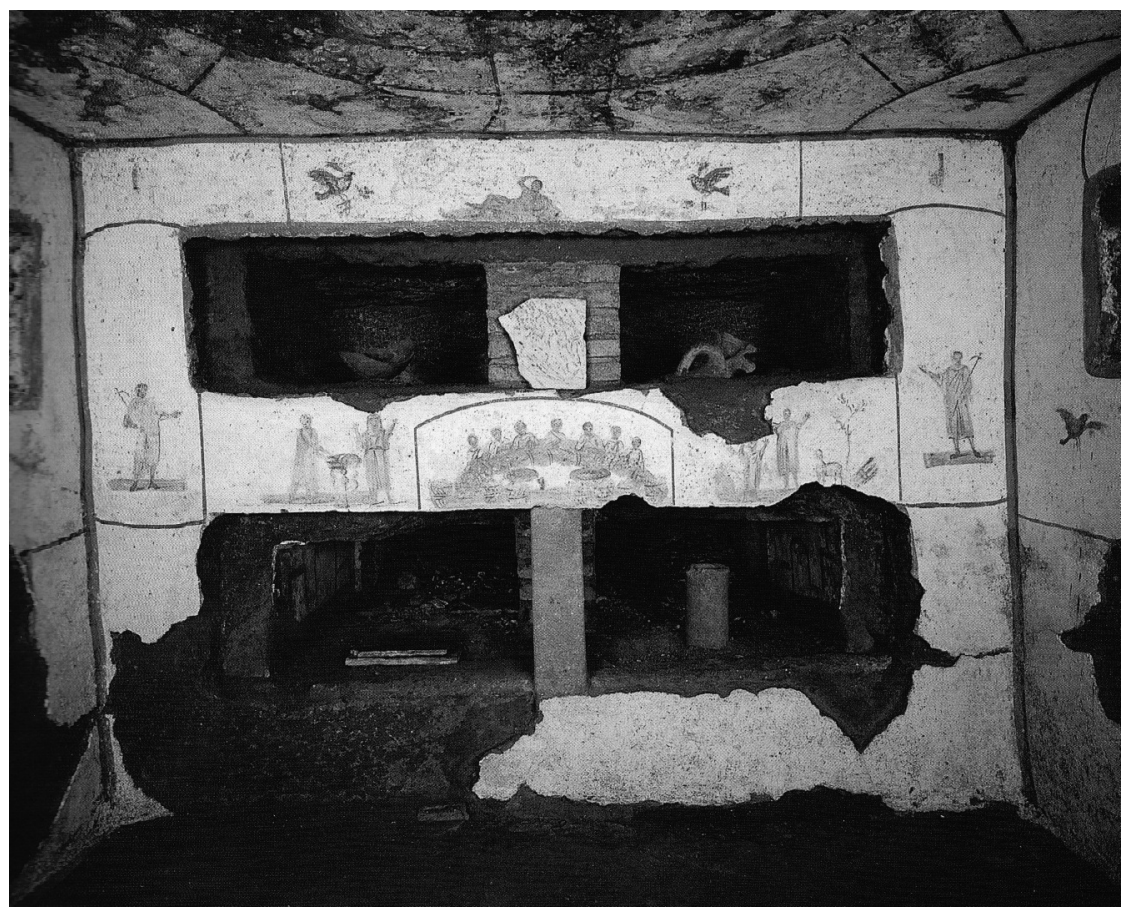

Fig. 13. Catacumba de San Calixto. Cubículo A3 de los Sacramentos. Pared de fondo (F. Bisconti, «La decoración...», p. 115).

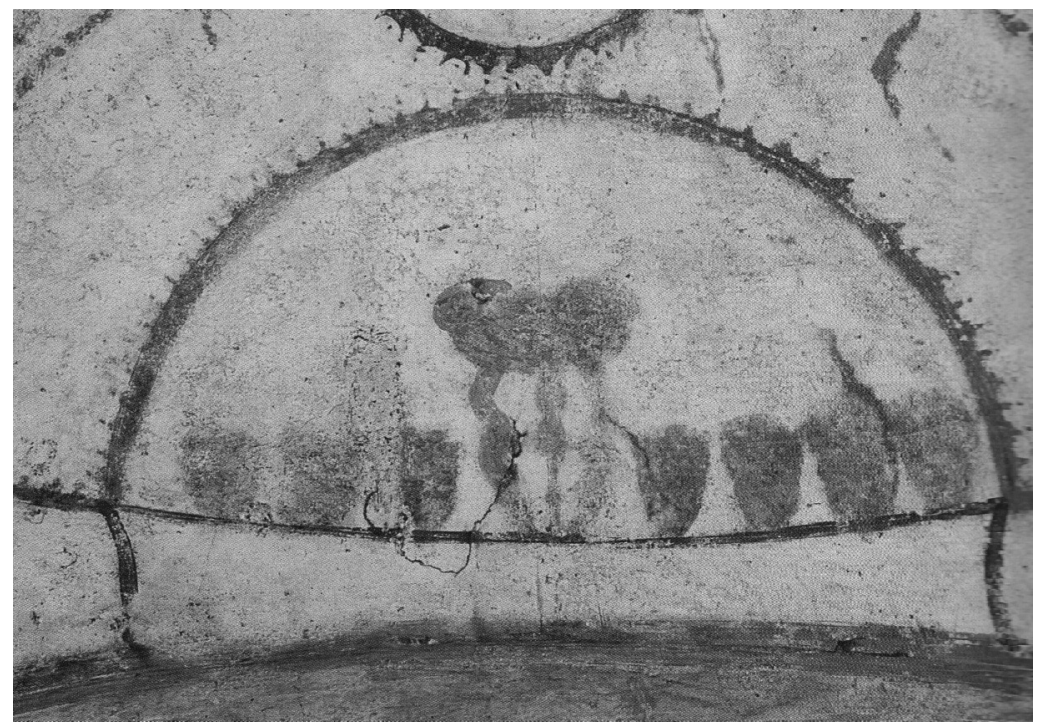

Fig. 14. Catacumba de San Calixto. Bóveda del cubículo A2 de los Sacramentos. Trípode y cestas de pan (F. Bisconti, "La decoración...», p. 112). 


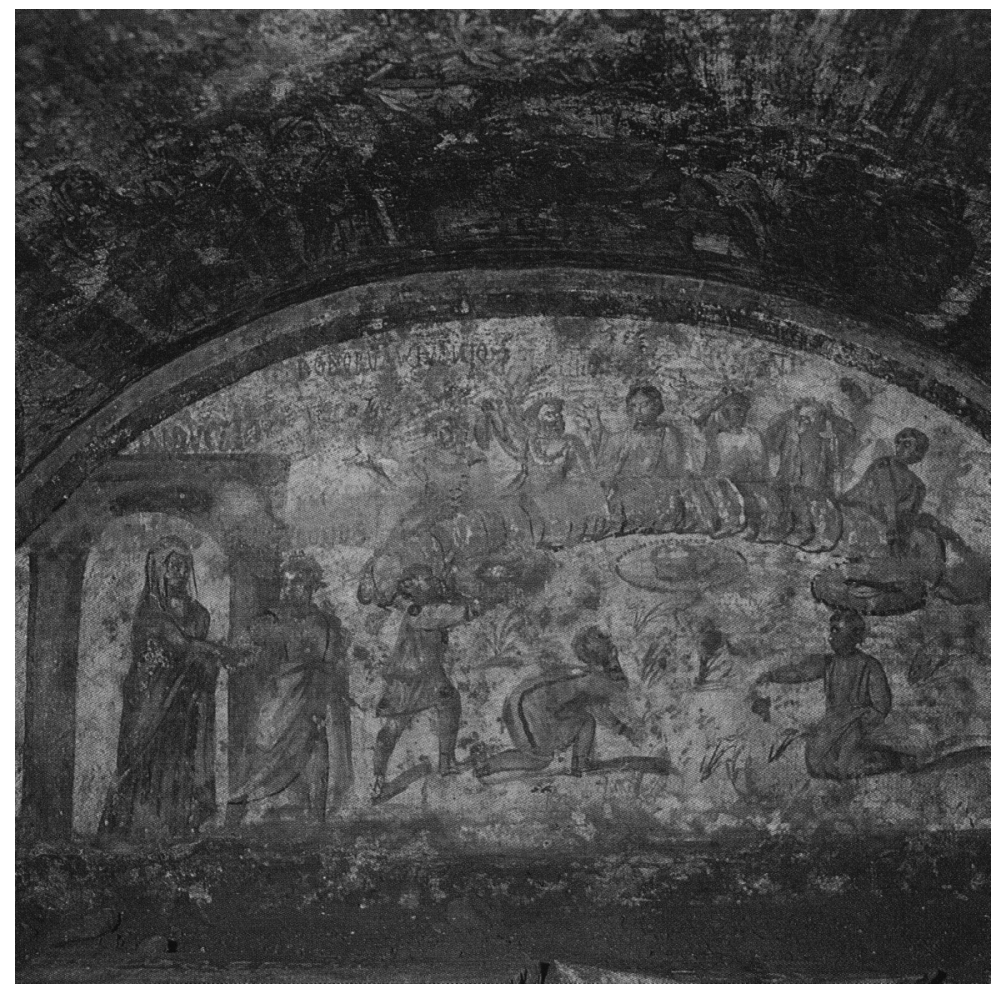

Fig. 15. Arcosolium del hipogeo de Vibia. Segunda mitad del siglo IV (K. M. D. Dunbabin, op. cit., Plate xv).

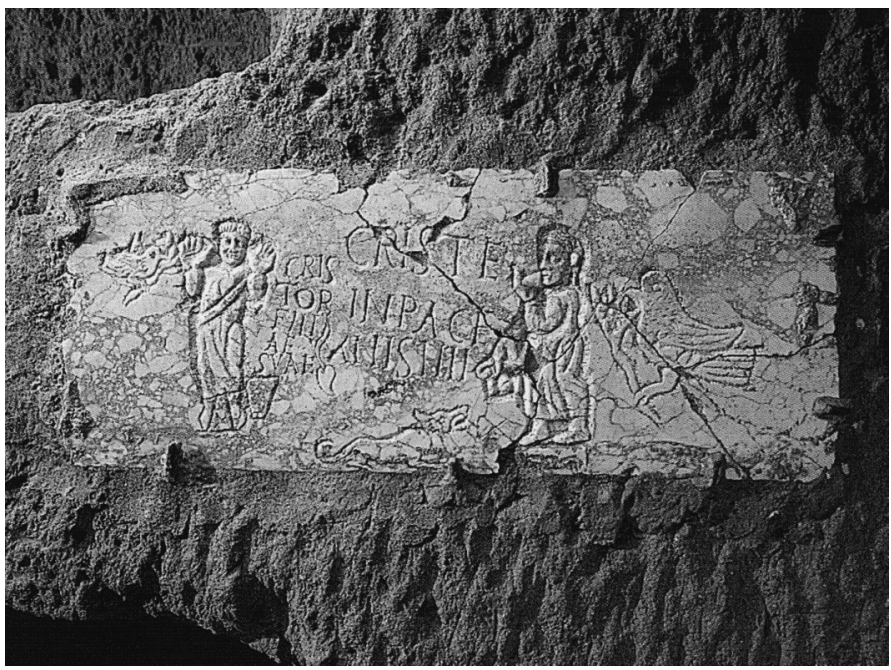

Fig. 16. Catacumba de Domitila. Lápida incisa de la difunta Criste (F. Bisconti, «La decoración...», p. 113). 
En conclusión, aunque los banquetes cristianos desarrollaron un ritual y una simbología religiosa muy particulares, debemos seguir afirmando, con M. Klinghardt, que «el ágape del cristianismo primitivo debe entenderse, pues, en toda su extensión como parte componente de la amplia cultura del simposio de la antigüedad grecorromana: tanto el origen de la praxis unitaria del banquete de los cristianos (no existían otras formas de experimentar la comunidad) como las diferentes interpretaciones del ágape —no sólo en los relatos institucionales sino también en los otros textos cristianos sobre el ágape- representan acentuaciones diferentes de esta antigua ideología del banquete» ${ }^{110}$.

Centre for Advanced Religious and Theological Studies,

University of Cambridge, junio de 2009 
